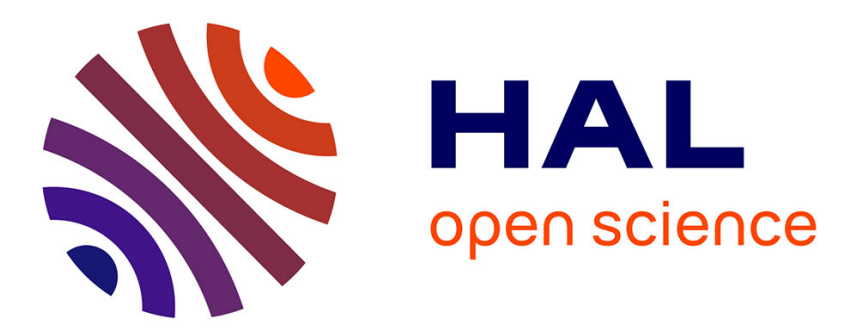

\title{
Quaternization of algal/PEI beads (a new sorbent): Characterization and application to scandium sorption from aqueous solutions
}

\author{
Mohammed Hamza, Yuezhou Wei, Eric Guibal
}

\section{To cite this version:}

Mohammed Hamza, Yuezhou Wei, Eric Guibal. Quaternization of algal/PEI beads (a new sorbent): Characterization and application to scandium sorption from aqueous solutions. Chemical Engineering Journal, 2020, 383, pp.123210. 10.1016/j.cej.2019.123210 . hal-02433212

\section{HAL Id: hal-02433212 \\ https://hal.mines-ales.fr/hal-02433212}

Submitted on 23 Jul 2020

HAL is a multi-disciplinary open access archive for the deposit and dissemination of scientific research documents, whether they are published or not. The documents may come from teaching and research institutions in France or abroad, or from public or private research centers.
L'archive ouverte pluridisciplinaire HAL, est destinée au dépôt et à la diffusion de documents scientifiques de niveau recherche, publiés ou non, émanant des établissements d'enseignement et de recherche français ou étrangers, des laboratoires publics ou privés. 


\title{
Quaternization of algal/PEI beads (a new sorbent): Characterization and application to scandium sorption from aqueous solutions
}

\author{
Mohammed F. Hamza ${ }^{\mathrm{a}, \mathrm{b}}$, Yuezhou Wei ${ }^{\mathrm{a}, \mathrm{c}, *}$, Eric Guibal ${ }^{\mathrm{d}, *}$ \\ ${ }^{a}$ Guangxi Key Laboratory of Processing for Non-ferrous Metals and Featured Materials, School of Resources, Environment and Materials, Guangxi University, Nanning \\ 530004, PR China \\ ${ }^{\mathrm{b}}$ Nuclear Materials Authority, POB 530, El-Maadi, Cairo, Egypt \\ ${ }^{\mathrm{c}}$ Shanghai Jiao Tong University, Shanghai, China \\ ${ }^{\mathrm{d}}$ C2MA, IMT - Mines Ales, Univ. Montpellier, Alès, France
}

\section{H I G H L I G H T S}

- Composite Algal/PEI beads successfully quaternized.

- Functionalized sorbent very efficient for Sc(III) sorption ( $3.8 \mathrm{mmol} \mathrm{Sc}^{-1}$ ).

- Kinetics controlled by pseudo-first order rate equation.

- Easy metal desorption and efficient sorbent recycling for 5 cycles.

- High efficiency and enrichment for Sc

(III) recovery from red mud effluent.

\section{A B S T R A C T}

Algal/Polyethyleneimine beads (APEI) were successfully quaternized to prepare an efficient sorbent (Q-APEI) for $\mathrm{Sc}(\mathrm{III})$ recovery. The functionalization has been confirmed by a series of analytical procedures: titration $\left(\mathrm{pH}_{\mathrm{PZC}}\right)$, elemental analysis, SEM, BET, EDX, FTIR, XPS and TGA. The sorption properties for Sc(III) from mild acidic

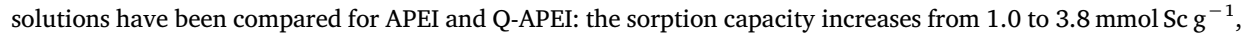
at the optimum pH; (i.e., 4.5). The porous structure (specific surface area close to $34 \mathrm{~m}^{2} \mathrm{~g}^{-1}$ ) of the sorbent allows reaching the equilibrium within $60-90 \mathrm{~min}$. Metal desorption is highly efficient using $0.5 \mathrm{M} \mathrm{HCl} / \mathrm{CaCl} 2$ solutions; the sorbent can be recycled for at least 5 cycles with limited decrease in sorption capacity. FTIR and XPS analysis confirm the stability of the material though some chemical changes can be observed. The sorption mechanism involves different reactive groups associated with the diversity of functional sites: carboxylate groups (from alginate) and more specifically amine groups (from PEI and quaternary amine grafted moieties) with contribution of different scandium species (free or scandium sulfate complexes), depending on the $\mathrm{pH}$. The sorbent is selective from $\mathrm{Mg}(\mathrm{II}), \mathrm{Sm}(\mathrm{III}), \mathrm{Ca}(\mathrm{II})$ and $\mathrm{Na}(\mathrm{I})$ (from equimolar synthetic solutions) at $\mathrm{pH}$ higher than 4. The application of Q-APEI for the sorption of Sc(III) from industrial solution (derived from red mud) shows that despite a high excess of iron, titanium or aluminum, scandium sorption is highly efficient (even at low metal concentration); though the sorbent is not selective.

Keywords:

Quaternization

Algal-PEI beads

Scandium

Sorption isotherms and uptake kinetics

Metal desorption

Material characterization

Sorption from red mud solution

\footnotetext{
*Corresponding authors at: School of Resources, Environment and Materials, Innovation Center for Metal Resources Utilization and Environment Protection,

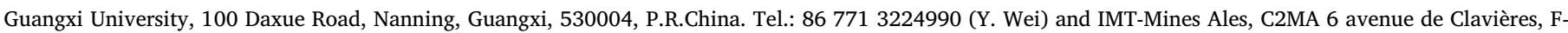
30319 Alès cedex, France. Tel.: + 33 (0)466782737 (E. Guibal).

E-mail addresses: yzwei@gxu.edu.cn (Y. Wei), Eric.Guibal@mines-ales.fr (E. Guibal).
} 


\section{Introduction}

Scandium is an important industrial metal mainly used for manufacturing solid oxide fuel cells (SOFC) (90\%) and enhanced aluminum alloys ( $9 \%$ ). It is also used (as scandium iodide) for manufacturing sunlike lamps and optical coatings (as $\mathrm{Sc}_{2} \mathrm{O}_{3}$ ). The world production just balances the industrial needs at around $15 \mathrm{t}$ per year [1]. There are only very few mining sites producing scandium worldwide (essentially in Scandinavian area); and the production is essentially considered a subproduct of other mining activities. The strong industrial development of fuel cells makes necessary the recovery and recycling of scandium from waste materials [2], mining [3] or metallurgy residues [4-6].

Leaching processes (sometimes associated to roasting, [7]) constitute the first step in the recovery of Sc(III) from solid wastes using acidic solutions $[6,8-10]$. For valorization of leachates, processes such as selective precipitation [11,12] and solvent extraction [13-16] are frequently reported for the treatment of concentrated solutions. The loss of expensive and toxic reagents (extractant and solvent being partially dissolved in water) makes solvent extraction environmentally and economically debatable in the case of dilute solutions (i.e., below $100-150 \mathrm{mg} \mathrm{Sc} \mathrm{L}^{-1}$ ).

Different types of sorbents have been reported for the sorption of scandium from dilute solutions, including (a) biosorbents such as yeast [17], bacteria [18] or algae [19], carbon-based materials [20], resins [21-24]; impregnated resins [25-27]. Recently a new generation of materials has been designed using the interactions of alginate and polyethyleneimine (PEI) for manufacturing bead sorbents [28]. Brown algal biomass was pre-treated with carbonate-containing solutions for the partial extraction of alginate and mixed with polyethyleneimine prior to reaction with calcium chloride and glutaraldehyde. Alginate was added to the mixture algal biomass and PEI to reinforce the strength of the hydrogel. The crosslinking of amine groups on PEI with glutaraldehyde and the ionotropic gelation of alginate fraction with calcium contribute both to the production of highly stable sorbents that were tested for palladium sorption. The presence of both carboxylate and amine groups make the sorbent multifunctional; in addition, these reactive groups, especially amine groups, open the possibility to functionalize this support (APEI) by grafting amidoxime groups (Wei et al., 2019, under review). The current work investigates the quaternization of APEI sorbent (herein referenced as $\mathrm{Q}-\mathrm{APEI}$ ) and compares the sorption properties of raw and functionalized materials for Sc(III) sorption from sulfate/sulfuric acid solutions. The rationale of this quaternization can be justified by the opportunity to bind metal anions on protonated amine groups on a wider $\mathrm{pH}$ range, to increase the selectivity for metal anions (under acidic conditions) over metal cations and to increase the density of sorption sites. Apart these specific interactions associated with the quaternization of APEI, the presence of $-\mathrm{OH}$ groups opens the route for metal binding through $\mathrm{Sc}-\mathrm{O}$ bonds while the carboxylate groups of alginate may bind Sc(III) through ion exchange with calcium ions (associated to the ionotropic gelation of alginate).

The first part of the manuscript describes the synthesis procedure with full analysis, including: morphology observation (SEM), determinations of specific surface area (BET surface) and $\mathrm{pH}_{\mathrm{PZC}}$ (surface charge), thermogravimetric analysis, FTIR, XPS spectroscopy, EDX characterization. The sorption properties of APEI and Q-APEI are compared for Sc(III) removal from sulfate solutions considering the effect of $\mathrm{pH}$, uptake kinetics, sorption isotherms, selectivity from multi-component solutions (containing also $\mathrm{Na}(\mathrm{I}), \mathrm{Ca}(\mathrm{II}), \mathrm{Mg}(\mathrm{II})$ and $\mathrm{Sm}(\mathrm{III})$ ), metal desorption and sorbent recycling. In the last part of the manuscript, Q-APEI is applied to the treatment of a real sample of Sc(III)-industrial by-product (red mud).

\section{Materials and methods}

\subsection{Materials}

Brown seaweed (Laminaria digitata) was provided by Setalg (Pleubian, France). After washing, drying and grinding, the biomass was sieved to recover the fraction below $250 \mu \mathrm{m}$. Alginate (Manugel GMB) was supplied by DuPont (Landerneau, France; now JRS Rettenmaier). Other reagents such as sodium carbonate, and calcium chloride were purchased from Chem-Lab NV (Zedelgem, Belgium). Branched polyethyleneimine (bPEI, $50 \%(w / w)$ in water), glutaraldehyde (GA, $50 \%(w / w)$ in water) were purchased from Sigma-Aldrich (Taufkirchen, Germany).

Scandium sulfate was used as a source of scandium for metal sorption experiments while samarium oxide was used in binary solutions; these salts were supplied by Damao Chemical Reagent Factory (Tianjin, China). Ethylene glycol diglycidyl ether, Glycidyltrimethylammonium chloride ( $\geq 95 \%$ ) were purchased from Shanghai Makclin Biochemical Co., Ltd. (Shanghai, China). $\mathrm{MgSO}_{4} \cdot 7 \mathrm{H}_{2} \mathrm{O}, \mathrm{CaO}$ and $\mathrm{Na}_{2} \mathrm{SO}_{4}$ used for preparing multicomponent solutions were purchased from Guangdong Guanghua Sci-Tech Co. Ltd (Guangdong, China).

\subsection{Synthesis of sorbents}

\subsubsection{APEI beads}

The algal/PEI beads were prepared according a method previously described by Wang et al. [28]. Briefly, $18.75 \mathrm{~g}$ of dry algal biomass was dispersed into $750 \mathrm{~mL}$ of $\mathrm{Na}_{2} \mathrm{CO}_{3}$ solution $(1 \%$, w/w) under agitation and heating $\left(50^{\circ} \mathrm{C}\right)$ for $24 \mathrm{~h}$. After cooling, a volume (i.e., $250 \mathrm{~mL}$ ) of alginate solution $(4 \%, \mathrm{w} / \mathrm{w})$ was added to biomass suspension. Five $\mathrm{mL}$ of bPEI solution $(50 \%, \mathrm{w} / \mathrm{w})$ were added to $500 \mathrm{~mL}$ of the mixture under agitation. The algal biomass/alginate/ bPEI suspension was distributed through a thin nozzle into a 1-L volume of a solution containing both $\mathrm{CaCl}_{2}(1 \%$, w/w) and GA $(5 \mathrm{~mL}, 50 \%$, w/w). The beads (APEI) were maintained under agitation overnight in the crosslinking solution before being filtrated and freeze-dried.

\subsubsection{Quaternization procedure - Q-APEI beads}

In order to increase the chemical stability of APEI beads an additional crosslinking step was applied. Poly(ethyleneglycol) diglycidyl ether $(3 \mathrm{~mL})$ was added in isopropanol $(90 \mathrm{~mL})$ before introducing $5 \mathrm{~g}$ of APEI beads. The suspension was refluxed for $4 \mathrm{~h}$ under agitation (agitation speed: $95 \mathrm{rpm}$ ). The crosslinked beads ('APEI) were then filtered off, washed with water and methanol and finally vacuum dried at $50^{\circ} \mathrm{C}$.

Five $\mathrm{g}$ of cross linked beads ( ${ }^{\mathrm{A}} \mathrm{APEI}$ ) were added to $140 \mathrm{~mL} \mathrm{DMF}: \mathrm{H}_{2} \mathrm{O}$ $(1: 1 \mathrm{v} / \mathrm{v})$ mixture in a three-necked flask. Glycidyltrimethylammonium chloride $(10 \mathrm{~g})$ was added to the suspension, which was refluxed at $73{ }^{\circ} \mathrm{C}$ for $24 \mathrm{~h}$ under gentle agitation. Finally, the beads (Q-APEI) were filtered off and washed three times with hot water, and methanol before being vacuum dried overnight at $50{ }^{\circ} \mathrm{C}$. Scheme AM1 (see Additional Material Section, AMS) summarizes the experimental procedure for the synthesis of Q-APEI.

\subsection{Characterization of sorbents}

Conventional analytical methods were used for characterizing the materials (APEI and Q-APEI) for elemental analysis, textural properties (BET analysis), thermogravimetric analysis (TGA analysis), morphological observation (SEM), chemical analysis (EDX for metal distribution, FTIR and XPS spectroscopy for functional groups analyses and evaluation of sorbent/metal ion interaction modes). These methods were previously described $[29,30]$. A brief reminder is reported in Additional Material Section (AMS).

\subsection{Sorption and desorption studies}

\subsubsection{Sorption and desorption steps}

Sorption properties have been tested in batch mode. A fixed volume of solution (V, L) containing given metal concentration $\left(\mathrm{C}_{0}\right.$ : mmol metal $\mathrm{L}^{-1}$ ) was mixed at $140 \mathrm{rpm}$ (on a reciprocal shaker) with a fixed amount of sorbent ( $\mathrm{m}, \mathrm{g}$, dry weight) at room temperature (i.e., $20 \pm 1{ }^{\circ} \mathrm{C}$ ) for given contact time. Samples were collected and filtered (using $1.2 \mu \mathrm{m}$ pore size filter membranes) before being analyzed for 
residual metal concentration $\left(\mathrm{C}_{\mathrm{eq}}\right.$ : $\mathrm{mmol}$ metal $\left.\mathrm{L}^{-1}\right)$. The $\mathrm{pH}$ was measured in the feed solution and at equilibrium (without $\mathrm{pH}$ adjustment during the sorption process). The sorption capacity ( $\mathrm{q}(\mathrm{t})$ or $\mathrm{q}_{\mathrm{eq}}$, mmolmetal $\mathrm{g}^{-1}$ ) was obtained by the mass balance equation: $\mathrm{q}=\left(\mathrm{C}_{0}-\mathrm{C}_{\mathrm{eq}}\right) \times \mathrm{V} / \mathrm{m}$. For uptake kinetics, samples were collected at different contact times and the kinetic profiles were plotted as a function of contact time. For sorption isotherms, initial concentration was varied between 0.05 and $11 \mathrm{mmol} \mathrm{Sc} \mathrm{L}^{-1}$ (all other parameters being set at the same values). In the case of metal sorption from multi-component solutions ( $\mathrm{Sc}(\mathrm{III}), \mathrm{Sm}(\mathrm{III}), \mathrm{Mg}(\mathrm{II}), \mathrm{Ca}(\mathrm{II})$ and $\mathrm{Na}(\mathrm{I})$ ), the in-

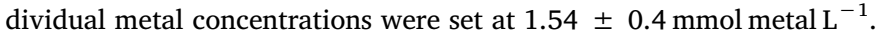

Experiments were not performed in buffered solutions (to prevent possible interactions with the sorbent or with metal ions). Therefore, a little decrease in the $\mathrm{pH}$ of the solution was observed for the two series. The initial pH set at 4.52 decreased to $4.45-4.19$ for the first series and to $4.46-4.14$ for the second series. These variations are considered negligible with limited impact on metal sorption.

Desorption kinetics were carried out using $0.5 \mathrm{M} \mathrm{HCl}+0.5 \mathrm{M} \mathrm{CaCl}_{2}$ solutions (calcium chloride being used for reinforcing the stability of the beads during the desorption). The Sc-loaded sorbent was collected from uptake kinetic experiments. For sorption and desorption cycles, the same experimental conditions were carried out for five successive cycles and the sorption and desorption efficiencies have been compared in order to evaluate the stability of sorption performances. Complementary characterization of the materials (FTIR and XPS spectroscopy) allowed evaluating the physico-chemical stability of the sorbent at re-use.

\subsubsection{Modeling}

Conventional models have been used for modeling uptake kinetics (i.e., pseudo-first order rate equation, PFORE, pseudo-second order rate equation, PSORE, Crank equation for resistance to intraparticle diffusion) $[31,32]$, sorption isotherms (i.e., Langmuir, Freundlich and Sips equations) [33]. The equations are summarized in Tables AM1-2 (see AMS). Model parameters were determined by non-linear regression analysis using Mathematica ${ }^{\circledR}$ software. For the modeling of desorption kinetics, the relevant PFORE and PSORE equations were used for determining apparent rate coefficients (Table AM3, see AMS).

\subsection{Industrial application}

Tests on real-like solutions were performed on industrial samples collected on local industrial facilities (Jinnao-Ti company, Tengxian, Guangxi, China) that produce red mud. The solution was diluted four times before being treated by sorption on Q-APEI. The effect of $\mathrm{pH}$ on the sorption of different elements was tested (i.e., Si, Zr, Ti, Fe, Al, and $\mathrm{Sc}$ ). The initial $\mathrm{pH}$ was adjusted using $0.1 / 1 \mathrm{M} \mathrm{NaOH}$ solutions or $0.1 / 1$ $\mathrm{M} \mathrm{H}_{2} \mathrm{SO}_{4}$ solutions. The $\mathrm{pH}$-controlled solutions were filtered on a filter membrane using a vacuum pump. The precipitates were characterized by EDX analysis. Sorption tests were performed by contact, under agitation, of $15 \mathrm{mg}$ of sorbent with $25 \mathrm{~mL}$ of diluted industrial solution for $20-48 \mathrm{~h}$. The final $\mathrm{pH}$ was measured and filtrated solutions were analyzed by ICP-AES for measuring the residual concentrations, calculating distribution and selectivity coefficients.

Note: Experimental conditions are systematically reported in the caption of relevant figures (both in the manuscript and the AMS).

\section{Results and discussion}

\subsection{Characterization of sorbents}

\subsubsection{Elemental analysis}

Table 1 compares the elemental analysis of APEI and Q-APEI. The most remarkable information concerns the relative increase in nitrogen content from $4.15 \mathrm{mmol} \mathrm{Ng}^{-1}$ to $6.12 \mathrm{mmol} \mathrm{Ng}^{-1}$. This means that approximately half of the amine groups are effectively quaternized. A part of this nitrogen comes from some fractions of the algal biomass (nitrogen
Table 1

Elemental analysis of APEI and Q-APEI.

\begin{tabular}{|c|c|c|c|c|c|c|}
\hline Sorbent & $\begin{array}{l}\mathrm{N} \\
{[\%]}\end{array}$ & $\begin{array}{l}\mathrm{N} \\
{\left[\mathrm{mmol} \mathrm{g}^{-1}\right]}\end{array}$ & $\begin{array}{l}\mathrm{C} \\
{[\%]}\end{array}$ & $\begin{array}{l}\mathrm{H} \\
{[\%]}\end{array}$ & $\begin{array}{l}\mathrm{O} \\
{[\%]}\end{array}$ & $\begin{array}{l}\mathrm{S} \\
{[\%]}\end{array}$ \\
\hline APEI & 5.81 & 4.15 & 39.86 & 6.00 & 29.48 & 0.44 \\
\hline Q-APEI & 8.57 & 6.12 & 42.09 & 8.68 & 33.34 & 0.44 \\
\hline
\end{tabular}

represents between 6 and $54 \mathrm{mg} \mathrm{N} \mathrm{g}^{-1}$ biomass), depending on the season and the location of algae harvesting [34], including as amino acids and proteins. However, most of the $\mathrm{N}$ is brought by PEI incorporation in the composite. Taking into account the fact that some of the amine groups on APEI are involved in weak interactions with carboxylic groups of alginate (including the biopolymer extracted from algal biomass) and strong interactions with aldehyde of the cross-linker agent (GA), it is possible assuming that the quaternization reaction is highly efficient. Branched PEI contains primary, secondary and tertiary amines (with respective proportions: 1/2/1) [35]. The GA crosslinking takes place preferentially on primary amine groups. This means that the quaternization probably involved secondary amine groups (and residual primary amine sites). By repeated quaternization steps, it was possible fully functionalizing all the amine groups [36]; however, the steric hindrance around tertiary amine, even complicated by the proper interactions of PEI with alginate and GA, makes difficult the reaction of quaternization on these sites.

\subsubsection{SEM and SEM-EDX analysis}

Tables AM 4-5 (see AMS) show the surface observation by SEM and the semi-quantitative analysis of APEI (as-produced) and Q-APEI at different stages of their use: as-produced, after Sc(III) sorption, after metal desorption and after 5 cycles of re-use. The surface of Q-APEI sorbent (both raw and after metal sorption) is poorly changed compared to APEI sorbent: the surface presents an irregular ridged structure with some small holes. After scandium binding, as expected the Sc peak appears accompanied by a strong S-element signal: this may be associated with either (or both) sulfate binding or sorption of Sc-sulfate species; in addition, the intensities of $\mathrm{Cl}$ and $\mathrm{Ca}$ peak are substantially reduced after metal sorption. A reverse trend is observed on sorbents exposed to desorption and successive recycles: the $\mathrm{Cl}$ and $\mathrm{Ca}$ peaks are restored; the eluting agent being constituted of both $\mathrm{HCl}$ and $\mathrm{CaCl}_{2}$. It is noteworthy that the ridges at the surface of the sorbent are remarkably increased: the surface is more irregular with more marked edges. The alternating steps of sorption and elution probably lead to local shrinking that increases the irregular aspect of the surface. Apart the physical shrinkage, the changes in the FTIR and XPS spectra demonstrate that the material was chemically modified after desorption and after re-use. This may be associated to amine cleavage in acidic solutions; however, the relative stability in sorption and desorption properties shows that the loss of amine groups is probably rather limited. The elemental analysis shows a little decrease in $\mathrm{N}$ content after scandium desorption.

\subsubsection{Textural analysis}

The textural analysis shows that the specific surface area is close to $34 \mathrm{~m}^{2} \mathrm{~g}^{-1}$ (Fig. AM1, see AMS). The pore volume is relatively low (close to $0.181 \mathrm{~cm}^{3} \mathrm{~g}^{-1}$ ) with pore size giving values of $230 \AA$ (sorption part of the curve) and $183 \AA$ (desorption part of the curve), with the BJH method (Table 2). The drying conditions for hydrogels strongly control the textural properties of dried materials [37]: (a) alcogels have higher porosity than hydrogels, (b) drying under super critical $\mathrm{CO}_{2}$ conditions (aerogels) develops higher specific surface area than cryogels (freeze-drying), while xerogels (oven-drying) have no detectable specific surface area. Alginate aerogels may have specific surface higher than $500 \mathrm{~m}^{2} \mathrm{~g}^{-1}[37,38]$, while cryogels reach values between 8 and $246 \mathrm{~m}^{2} \mathrm{~g}^{-1}$, depending on gelation conditions [37]. The current process of fabrication includes a freeze-drying step for the preparation of APEI beads; after the chemical modification, the final material was vacuum- 
Table 2

Textural and morphological properties of Q-APEI sorbent.

\begin{tabular}{ll}
\hline Properties & Q-APEI \\
\hline Bead size $(\mathrm{mm})$ & $2.80 \pm 0.36$ \\
Specific surface area $\left(\mathrm{m}^{2} \mathrm{~g}^{-1}\right)$ & 34 \\
Porous volume $\left(\mathrm{cm}^{3} \mathrm{~g}^{-1}\right)$ & 0.181 \\
Pore size (nm) & $183-230$ \\
\hline
\end{tabular}

dried. The specific surface area is maintained at a relatively good level for a material dried under drastic conditions: the structuration of the original material resulting from crosslinking of PEI with glutaraldehyde and the ionotropic gelation of carboxylate groups of alginate/algal biomass with calcium retains good porosity. This is of same order than the specific surface area obtained with the amidoximation of APEI beads (around $40 \mathrm{~m}^{2} \mathrm{~g}^{-1}$, Wei et al., under submission).

\subsubsection{FTIR spectroscopy}

The FTIR spectra and the assignments of most representative peaks for APEI, Q-APEI are reported in Fig. AM2 and Table AM5 (see AMS). The quaternization of APEI beads is confirmed by: (a) the shift of the $-\mathrm{C}=\mathrm{N}-$ (from $1632 \mathrm{~cm}^{-1}$ to $1618 \mathrm{~cm}^{-1}$ ), and (b) the appearance of a new peak at $1468 \mathrm{~cm}^{-1}$, which is assigned to asymmetric $\mathrm{C}-\mathrm{H}$ bend in methylene groups linked to $\mathrm{N}^{+}$(in quaternary ammonium salt).

The analysis of scandium-loaded sorbent (Q-APEI) shows essentially four changes:

(a) The $-\mathrm{C}=\mathrm{N}$ signal is shifted back to its original position (i.e., $1632 \mathrm{~cm}^{-1}$ ).

(b) The asymmetric $\mathrm{C}-\mathrm{H}$ bending (methylene groups) linked to $\mathrm{N}^{+}$is shifted to $1475 \mathrm{~cm}^{-1}$.

(c) The $\mathrm{C}-\mathrm{O}$ stretching vibration (primary and secondary alcohol groups) is slightly shifted.

(d) The signal appearing at $617 \mathrm{~cm}^{-1}$ is assigned to sulfate ion.

Scandium ion binds on Q-APEI under the form of its sulfate complex; in addition, the environments of tertiary amine groups and $\mathrm{C}-\mathrm{O}$ groups are modified by metal sorption. After metal desorption, these groups are also significantly affected: the peaks are shifted (without reaching their original wavenumbers). The regeneration of the sorbent with $\mathrm{HCl} / \mathrm{CaCl}_{2}$ solution affects the environment of reactive groups (protonation, $\mathrm{Ca}(\mathrm{II})$ ion-exchange).

\subsubsection{XPS spectroscopy}

The comparison of XPS spectra of APEI and Q-APEI allows characterizing the grafting of quaternary ammonium salt. The overall XPS survey of the two materials is not significantly changed: the same elements are present (Fig. AM3, see AMS). The metal binding and desorption can be characterized by the appearance of peaks specific to Sc element (i.e., Sc $2 p$, Sc $2 s$, Sc $3 p$, Sc $3 s$ Sc $L M 3$ ) $[39,40]$ but also to S element (i.e., $S 2 p$ and $S 2 s$ ) (Table AM6-9, see AMS). The metal is bound, at least partially, under its sulfate complex and the weak $\mathrm{Ca}$ signal (Ca 2p) disappears. After metal desorption, both Sc and S element disappear, while the signals representing $\mathrm{Cl}$ element (i.e., $\mathrm{Cl} 2 p$ and $\mathrm{Cl}$ $2 s$ ) and Ca element (i.e., Ca $2 p$ and Ca $2 s$ ) strongly increase: scandium sulfate species are desorbed and replaced with $\mathrm{Ca}(\mathrm{II})$ and $\mathrm{Cl}^{-}$.

The HRES of the materials shows much significant information for $\mathrm{C}$ $1 s$ and $\mathrm{N} 1 s$ signals. Tables AM6 and AM7 (see AMS) show that the grafting of quaternary amine involves some changes in the environment of C $1 s$ signal. In APEI, the signal can be deconvoluted into C (adventitious $\mathrm{C}, \mathrm{C}-\mathrm{H})$ at $284.27 \mathrm{eV}$ [30], $\mathrm{C}\left(\mathrm{NH}, \mathrm{NH}_{2}\right)$ at $285.41 \mathrm{eV}$ [30], $\mathrm{C}(-\mathrm{O},=\mathrm{N})$ at $286.08 \mathrm{eV}$ [41], $\mathrm{C}(=\mathrm{O},-\mathrm{O}-\mathrm{C})$ at $287.6 \mathrm{eV}$ [42], and $\mathrm{O}-\mathrm{C}(=\mathrm{O},-\mathrm{O})$ at $288.44 \mathrm{eV}$ [41]. After quaternization, the $\mathrm{C}(-\mathrm{NH}$ or $-\mathrm{NH}_{2}$ ) band disappears and is replaced by the band representing quaternary ammonium group. At the meantime for the quaternary ammonium sorbent $\mathrm{C} 1 s$ has four individual peaks at $284.97 \mathrm{eV}$, $286.86 \mathrm{eV}, 287.92 \mathrm{eV}$ are assigned to $\mathrm{C}$ (adventitious $\mathrm{C}$, and $\mathrm{C}-\mathrm{H}$ ), C $(\mathrm{N}), \mathrm{C}(-\mathrm{O},=\mathrm{N})$; the binding energy at $288.58 \mathrm{eV}$ corresponds to the overlapping $\mathrm{C}(=\mathrm{O},-\mathrm{O}-\mathrm{C})$ and $\mathrm{O}-\mathrm{C}(=\mathrm{O},-\mathrm{O})$ signals [43]. The $\mathrm{O} 1 \mathrm{~s}$ signal is poorly affected by chemical modification: three bands appear at $529.29 \mathrm{eV}, 530.7 \mathrm{eV}, 532.27 \mathrm{eV}$ for $\mathrm{O}-\mathrm{Ca}, \mathrm{C}=\mathrm{O}$ and $\mathrm{O}(-\mathrm{C}, \mathrm{H})$ signals [44-47], respectively. After quaternization, the $\mathrm{O} 1 s$ bands are relatively stable with only limited shifts in binding energies. The deconvolution of $\mathrm{N} 1 s$ signals shows, on APEI material, two peaks at $399.2 \mathrm{eV}$ and $401.34 \mathrm{eV}$ that are assigned to $\mathrm{N}(-\mathrm{C},=\mathrm{C},-\mathrm{H})$ and $\mathrm{N}^{+}$ respectively $[29,48]$. After quaternization a new peak appears at $399.7 \mathrm{eV}$, which is attributed to tertiary amine group, while the peak at $399.2 \mathrm{eV}$ (assigned to $\mathrm{N}(\mathrm{C},=\mathrm{CH})$ is shifted to $398.44 \mathrm{eV}$ and the $\mathrm{N}^{+}$ signal appears at $401.65 \mathrm{eV}$ [49]; this confirms the efficient chemical modification of APEI beads.

After Sc(III) binding, substantial changes are observed:

(a) $\mathrm{C}$ 1s: $\mathrm{C}(=\mathrm{O},-\mathrm{O}-\mathrm{C})$ and $\mathrm{O}-\mathrm{C}(=\mathrm{O},-\mathrm{O})$ bands overlap at $\mathrm{BE}$ : $287.64 \mathrm{eV}$ while $\mathrm{C}(-\mathrm{O},=\mathrm{N})$ band is identified at $286.01 \mathrm{eV}$ and $\mathrm{C}$ $(\mathrm{C}, \mathrm{H})$, and $\mathrm{C}(\mathrm{N})$ are split at $284.04 \mathrm{eV}$ and $284.71 \mathrm{eV}$, respectively [49],

(b) $\mathrm{N} 1 s$ : a new peak appears at BE: $406.3 \mathrm{eV}$, which is assigned to $\mathrm{N}-\mathrm{Sc}$ [50], while the other two peaks at $398.8 \mathrm{eV}$ for $\mathrm{N}(\mathrm{C},=\mathrm{C}, \mathrm{H})$ overlapped with $\mathrm{N}_{\text {tert }}$ and $401.72 \mathrm{eV}$, which are associated to the quaternary ammonium groups. The $\mathrm{N}_{\text {tert. }}$ peak is shifted from $399.7 \mathrm{eV}$ to $398.8 \mathrm{eV}$.

(c) O1s: five peaks appear in the deconvolution of the band; at $\mathrm{BE}$ : $529.15 \mathrm{eV}$ for $\mathrm{O}-\mathrm{Ca}, 530.86 \mathrm{eV}$ for $\mathrm{C}=\mathrm{O}$ overlapped with $\mathrm{C}-\mathrm{O}$, $533.65 \mathrm{eV}$ for $\mathrm{OH}, 532.65 \mathrm{eV}$ for $\mathrm{O}-\mathrm{S}$ of sulfate group [39,51] and $527.9 \mathrm{eV}$ for $\mathrm{O}-\mathrm{Sc}[39,52]$. This means that oxygen on hydroxyl groups and carboxylate are involved in Sc(III) sorption.

(d) S 2p: the sulfate peak (originally identified at BE: $168.01 \mathrm{eV}$ ) is split into two peaks at $168.05 \mathrm{eV}$ and $169.3 \mathrm{eV}$, while the $S 2 p_{1 / 2}$ at $168.98 \mathrm{eV}$ disappears.

After Sc(III) desorption from loaded sorbent, the HRES for main elements are globally restored. Main changes are detected on the BE values. For example, after desorption with $0.5 \mathrm{M} \mathrm{HCl} / \mathrm{CaCl}_{2}$ solution the $\mathrm{N}_{\text {tert. }}$ peak is shifted to $400.76 \mathrm{eV}$ (399.7 eV on Q-APEI), $\mathrm{C}=\mathrm{O},-\mathrm{O}-\mathrm{C}$, $\mathrm{O}-\mathrm{C}=\mathrm{O}, \mathrm{O}-\mathrm{C}-\mathrm{O}$ bands are also shifted. The desorption slightly affects the material but the presence of calcium chloride contributes to stabilize the sorbent (Tables AM8-9, see AMS).

The semi quantitative analysis of the sorbent (at the different stages) deduced from XPS analysis is summarized on Table AM5 (see AMS). The increased atomic fraction (AF) of N in Q-APEI (compared to APEI) confirms the successful quaternization of the sorbent, which is followed by a relative decrease of $\mathrm{Ca} \mathrm{AF}$ and the appearance of $\mathrm{Cl}$ (counter anion of quaternary ammonium groups). After metal sorption Sc element appears while $\mathrm{Cl}$ AF strongly decreases and $\mathrm{S} \mathrm{AF}$ increases to 2.14\%: $\mathrm{Sc}(\mathrm{III})$ is bound under its sulfate form. This is confirmed by the substantial increase of O AF. Surprisingly N AF is almost doubled. After metal desorption, $\mathrm{S}$ and Sc completely disappear; $\mathrm{Cl}$ AF increases again to a level close to the original level, $\mathrm{C}, \mathrm{O}$ and $\mathrm{N}$ AFs approaches their original values and $\mathrm{Ca} \mathrm{AF}$ is increased as part of the ion-exchange mechanism.

These analyses show that several reactive groups may be involved in $\mathrm{Sc}(\mathrm{III})$ binding due to the diversity of functional groups present on the sorbents. The chemical environment of $\mathrm{N}, \mathrm{O}$ are modified due to $\mathrm{Sc}(\mathrm{III})$ binding with contribution of sulfate groups (Sc-sulfate complex bound to Q-APEI): $\mathrm{Sc}-\mathrm{O}$ and $\mathrm{Sc}-\mathrm{N}$ bands are clearly identified through deprotonation effects on $-\mathrm{OH}$ groups and also due to the electron-withdrawing effect of quaternary ammonium on neighboring hydroxyl groups.

\subsubsection{Thermogravimetric analysis}

Fig. AM4 (see AMS) compares the TGA profiles of APEI and Q-APEI. Substantial changes are observed after functionalization of APEI: shifts of the waives (temperature ranges and relative values) for weight loss 
(Fig. AM4a). These changes appear even more on Fig. AM4b that represents the DrDTG: the peaks identify the temperatures where the weight losses are the most important. For temperatures below $190^{\circ} \mathrm{C}$ and $205^{\circ} \mathrm{C}$, the two sorbents lose superficial and internal water (which represent a loss between 10 and $21 \%$, in weight). A second decomposition step (mass loss close to $41 \%$ ) occurs between 190 and $304{ }^{\circ} \mathrm{C}$ for APEI, this is usually associated to the cleavage of saccharide ring and ester group in alginate (and relevant analogues in the algal biomass). The DrDTG curve shows two peaks at $226^{\circ} \mathrm{C}$ and $300^{\circ} \mathrm{C}$. The TGA of alginate ionotropically gelled with $\mathrm{Ca}(\mathrm{II})$ also shows similar profile [53]; the o ccurrence of two distinct d ecomposition processes was attributed to the presence of calcium and the egg-box structure associated with alginate-Ca interaction. The thermal degradation of Laminaria digitata also shows two temperatures of maximum degradation at $\approx 250^{\circ} \mathrm{C}$ (alginic acid degradation) and $280-300{ }^{\circ} \mathrm{C}$ (degradation of sugars) [54]. This transition is observed between $205^{\circ} \mathrm{C}$ and $381^{\circ} \mathrm{C}$ for Q-APEI (with a single peak on DrDTG profile at $226^{\circ} \mathrm{C}$ ). Unexpectedly, the functionalized material shows a simpler pattern of anaerobic decomposition. The third step in the thermal degradation of APEI occurs above $304^{\circ} \mathrm{C}$; the weight loss stops at $554^{\circ} \mathrm{C}$. This is assigned to the degradation of the main chains of PEI [55].

Obviously, the complexity of the composite materials including many compounds apart alginate and PEI (such as the constituents of algal biomass) make debatable the discussion and assignment of degradation steps, especially because of the effect of alginate extraction during the synthesis procedure and its interactions with other compounds (PEI, GA).

It is noteworthy that the functionalized derivative of APEI has a lower stability at high temperature: while the final residue is close to $12 \%$ for APEI residue (stable above $554^{\circ} \mathrm{C}$ ), for Q-APEI the residue decreases to $3 \%$ at $800{ }^{\circ} \mathrm{C}$. This may be of interest at the end of the life cycle of the sorbent for its final elimination.

\subsection{7. $p H_{P Z C}$}

Fig. AM5 (see AMS) compares the pH-drift titration of APEI and QAPEI sorbents. The $\mathrm{pH}_{\mathrm{PZC}}$ of APEI is close to 4.9. This value can be correlated to the combined effects of different functional groups present on the composite beads. The sorbent contains: (a) carboxylic groups from algal/alginate based materials, with $\mathrm{pK}_{\mathrm{a}}$ values of 3.38 (mannuronic acid) and 3.65 (guluronic acid [56]), and (b) amine groups from PEI with $\mathrm{pK}_{\mathrm{a}}$ values of 4.5 (primary amines), 6.7 (secondary amines) and 11.6 (tertiary amines) [57]. Below pH 4.9, the equilibrium $\mathrm{pH}$ value slightly increases (by less than $0.3 \mathrm{pH}$ unit) while above $\mathrm{pH}_{\mathrm{PZC}}$ the equilibrium $\mathrm{pH}$ drastically decreases (by about $2.7 \mathrm{pH}$ unit at the maximum amplitude; i.e., at $\mathrm{pH} 9$ ). The quaternization of the material induces a strong shift for $\mathrm{pH}_{\mathrm{PZC}}$, up to 6.77: the grafting of quaternary ammonium groups means a positive charge of the material on a wider $\mathrm{pH}$ range (including close to neutral $\mathrm{pH}$ ). Below $\mathrm{pH} 6.77, \mathrm{pH}$ variation does not exceed 0.7 unit, while in the alkaline region $\mathrm{pH}$ decrease may reach up to 1.4 unit. The increase of $\mathrm{pH}_{\mathrm{PZC}}$ value with quaternization is consistent with the results reported by Sun et al. [58] for the chemical modification of activated carbon.

\subsection{Sorption performances}

\subsection{1. $p H$ effect}

Fig. 1 shows the effect of $\mathrm{pH}$ on $\mathrm{Sc}(\mathrm{III})$ sorption for APEI and Q-APEI sorbents. The two sorbents have limited sorption capacities at $\mathrm{pH}$ close to 1 (i.e., $0.08 \mathrm{mmol} \mathrm{Scg}^{-1}$ ). Fig. AM6 (see AMS) shows the speciation diagram of Sc-(III) in sulfate/sulfuric acid solutions. At pH 1, anionic Sc (III) species (i.e., $\mathrm{Sc}\left(\mathrm{SO}_{4}\right)_{2}{ }^{-}$) represents about $15 \%$ of total scandium (other species being cationic: mainly $\mathrm{ScSO}_{4}{ }^{+}$but also $\mathrm{Sc}^{3+}$ ). On the other side, both APEI and Q-APEI are strongly protonated. Limited metal sorption probably occurred through anionic Sc(III) species binding on protonated amine groups (PEI groups, quaternary ammonium salt). Increasing the $\mathrm{pH}$ improves the sorption capacity due to the progressive
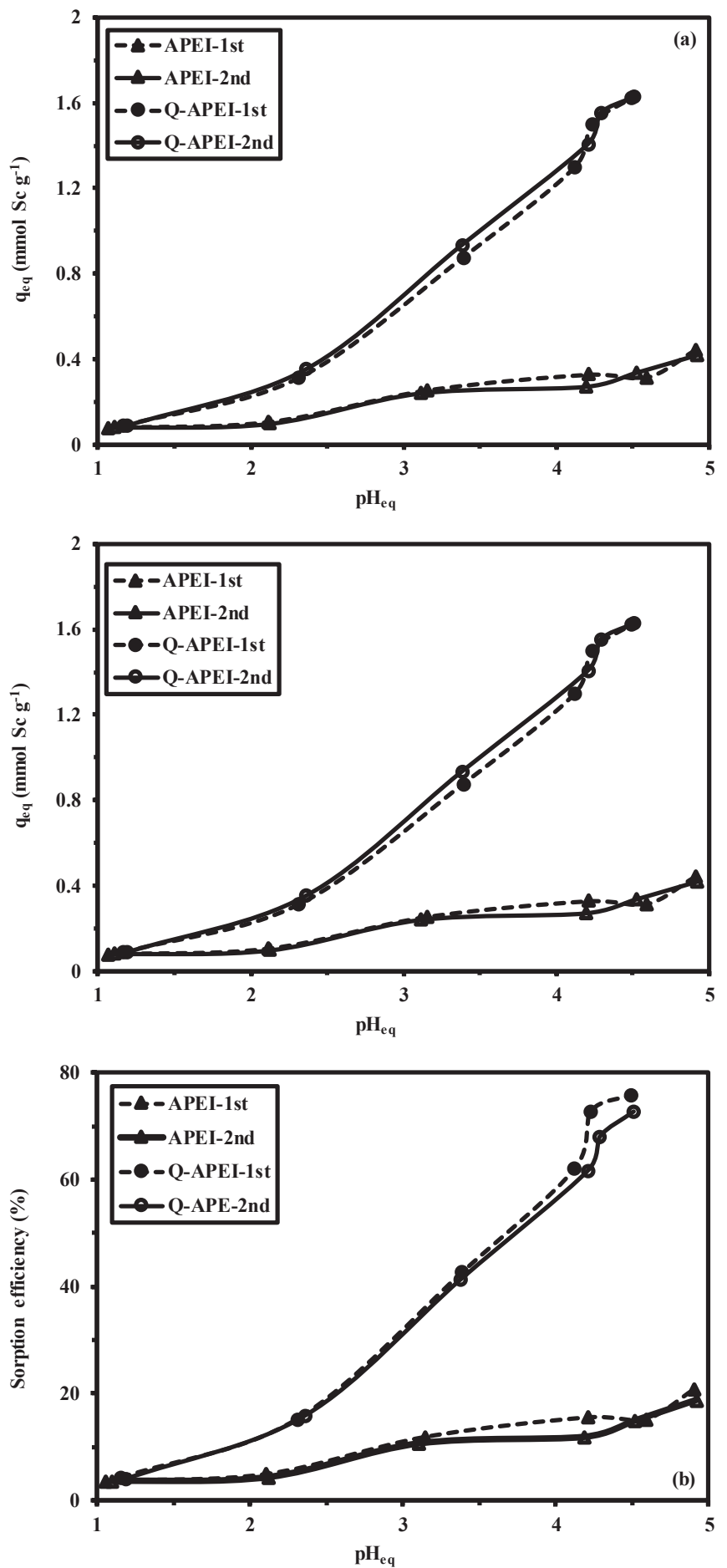

Fig. 1. Influence of $\mathrm{pH}$ on $\mathrm{Sc}(\mathrm{III})$ sorption using APEI and Q-APEI: (a) sorption capacity, (b) sorption efficiency $\left(\mathrm{C}_{0}:: 1.1 \mathrm{mmol} \mathrm{Sc} \mathrm{L}^{-1}\right.$; Sorbent dosage, SD: $0.5 \mathrm{~g} \mathrm{~L}^{-1}$; Contact time: $48 \mathrm{~h}$; Temperature: $20 \pm 1{ }^{\circ} \mathrm{C}$; Agitation: $140 \mathrm{rpm}$ ).

decrease in the competition effect of protons. In the case of APEI beads, the deprotonation of carboxylic groups, above $\mathrm{pH} 3.5$, makes possible the binding of cationic species (including $\mathrm{Sc}^{3+}$ and $\mathrm{ScSO}_{4}{ }^{+}$). However, the sorption levels are rather limited: under selected experimental conditions, $q_{\text {eq }}$ value does not exceed $0.42 \mathrm{mmol} \mathrm{Sc}^{-1}$. The quaternization of APEI strongly improves Sc(III) sorption: from $\mathrm{pH} 1$ to 2.4, the sorption capacity increases from 0.07 to $0.36 \mathrm{mmol} \mathrm{Scg}^{-1}$; above $\mathrm{pH} 2.4$, the capacity linearly increases up to $1.6 \mathrm{mmol} \mathrm{Sc}^{-1}$. This enhancement of metal sorption can probably be explained by several reasons associated to deprotonation of carboxylic groups, decrease in the competition of 
protons for binding on reactive groups. The $\mathrm{pH}_{\mathrm{PZC}}$ of the materials is strongly shifted toward higher value after quaternization. This apparent contradictory effect: quaternization for increase in cationic density and beneficial effect of deprotonation can be explained by the withdrawing effect of q uaternary a mmonium $\mathrm{g}$ roups o $\mathrm{n} \mathrm{v}$ icinal $-\mathrm{OH} \mathrm{g}$ roups. A s a consequence, the $-\mathrm{OH}$ groups are slightly deprotonated making possible the binding of cationic Sc(III)-sulfate species. On the other hand, the decrease in $\mathrm{Cl}^{-}$content, shown by semi-quantitative XPS analysis, confirms that $\mathrm{i}$ on-exchange $\mathrm{m}$ echanism o $\mathrm{n} \mathrm{p}$ rotonated a mine (including quaternary ammonium salt) is also involved in the binding mechanism.

The $\mathrm{pH}$ variation during metal sorption is represented on Fig. AM7 (see AMS). Between pH 1 and 4, the sorption of Sc(III) hardly changes the $\mathrm{pH}$ of the solution for APEI, while a little increase is observed for QAPEI: the variation does not exceed $0.4 \mathrm{pH}$ unit. For both APEI and QAPEI, the variation is less than reported observations in $0.1 \mathrm{M} \mathrm{NaCl}$ solutions (for the determination of $\mathrm{pH}_{\mathrm{PZC}}$ ). Above $\mathrm{pH} 4$, reciprocal trends are observed. Indeed, for Q-APEI sorbent $\mathrm{pH}$ variation tends to be negligible while $\mathrm{Sc}$ (III) sorption is followed by a decrease of $\mathrm{pH}$ (by $0.5 \mathrm{pH}$ unit) in the case of APEI. This is another evidence that the quaternization changes the acid-base properties of the material (activation of proton release on $-\mathrm{OH}$ grafted groups of glycidyl group) and Sc(III) binding mechanism.

The linearization of the distribution ratio ( $D=\mathrm{q}_{\mathrm{eq}} / \mathrm{C}_{\mathrm{eq}}, \mathrm{Lg}^{-1}$ ) (in $\log$ plot) $v$ s. equilibrium $\mathrm{pH}$ is frequently used for evaluating the protonexchange stoichiometry [59]. The slope of the plot is supposed to give the stoichometric ratio in proton exchange and sorbed metal species; and then to evaluate the charge of preferentially bound species. Fig. AM8 (see AMS) shows the plot of $\log _{10} \mathrm{D} v s . \mathrm{pH}_{\mathrm{eq}}$. The slopes for APEI and Q-APEI are respectively 0.21 and 0.55 . Obviously, in the case of sorbent bearing different reactive groups and/or involving different mechanisms the interpretation is not straightforward. For example, for APEI the interpretation of the slope cannot address the stoichiometric ratio between metal species and protons exchanged (released protons, charge of Scsulfate anion). Additional mechanisms may be involved for explaining the stoichiometric ratio including ligand exchanges on Sc-sulfate cations, sulfate interaction with protons (to form hydrogen sulfate), binding of different species on APEI and competitive binding of sulfate or hydrogen sulfate ions [59]. In the case of Q-APEI; the slope is close to 0.5. In this case also it is difficult connecting this slope to the species potentially bound on the sorbent and to the proton exchange because of the diversity of metal species, reactive groups and binding mechanisms.

Based on these observations, in complement to FTIR and XPS analysis, the mechanisms involved in Sc(III) may consist of a combination (depending on the $\mathrm{pH}$ ) of:

(a) binding on carboxylate groups (at $\mathrm{pH}$ higher than 3.5), and on partially deprotonated $-\mathrm{OH}$ groups (assisted by the electron-withdrawing effect of vicinal quaternary ammonium salt),

(b) uptake of Sc-sulfate anions on protonated amine groups (including quaternary ammonium salt) in acidic solutions,

(c) binding of $\mathrm{Sc}$ (III) on free amine groups at mild-acidic $\mathrm{pH}$.

\subsubsection{Uptake kinetics}

The mass transfer of metal species can be controlled by several mechanisms of resistance to diffusion (bulk, film and intraparticle diffusions), in addition to the proper reaction rates (including counter ion exchanges). Providing to the system a sufficient agitation allows neglecting the contribution of limitations due to bulk diffusion and minimizing the effect of resistance to film diffusion. The sorption mechanisms are thus frequently controlled by the resistance to intraparticle diffusion (herein simulated by the Crank equation, RIDE) and/or the reaction rate (chelation, ion-exchange being simulated using the pseudo-first order rate equation or the pseudo-second order rate equation, PFORE and PSORE, respectively). Fig. 2 shows the kinetic profiles for Sc(III) sorption using APEI and Q-APEI. Under selected experimental conditions, the sorption is relatively fast: uptake reaches the equilibrium within 60-90 min. The three models have

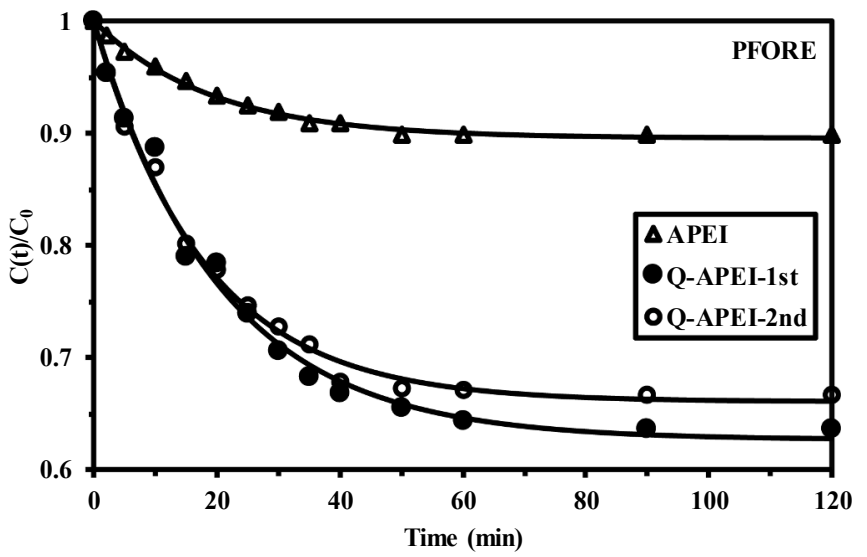

Fig. 2. $\mathrm{Sc}(\mathrm{III})$ sorption kinetics using $\mathrm{APEI}$ and Q-APEI - PFORE modeling $\left(\mathrm{C}_{0}\right.$ : : $1.1 \mathrm{mmol} \mathrm{Sc} \mathrm{L}^{-1}\left(\mathrm{C}_{0}: 1.25 \mathrm{mmol} \mathrm{Sc} \mathrm{L}^{-1}\right.$ for 2nd experiment); $\mathrm{SD}: 0.25 \mathrm{~g} \mathrm{~L}^{-1}$; $\mathrm{pH}_{0}$ : 4.5; $\mathrm{pH}_{\mathrm{eq}}$ : 4.2-4.6; Temperature: $20 \pm 1^{\circ} \mathrm{C}$; Agitation: $140 \mathrm{rpm}$ ).

been applied to experimental data: Table 3 reports their specific parameters and the corresponding determination coefficients. Based on the comparison of determination coefficients and experimental/calculated values of the sorption capacity at equilibrium, the model that fits better kinetic profiles is the PFORE (shown in Fig. 2). The fits of experimental curves with RIDE are represented in Fig. AM9 (see AMS): the kinetic trends are globally respected though less accurately than PFORE. The apparent rate coefficient $\left(\mathrm{k}_{1}, \mathrm{~min}^{-1}\right)$ is poorly affected by the quaternization of APEI beads: the value varies between 0.049 and $0.056 \mathrm{~min}^{-1}$ (APEI and duplicated experiments on Q-APEI, with weak change in experimental value of $\mathrm{C}_{0}$ ). The evaluation of the effective diffusion coefficient $\left(D_{e}, \mathrm{~m}^{2} \mathrm{~min}^{-1}\right)$ confirms the weak impact of chemical material on the diffusion behavior of the beads: $\mathrm{D}_{\mathrm{e}}$ varies between $1.37 \times 10^{-8}$ and $1.94 \times 10^{-8} \mathrm{~m}^{2} \mathrm{~min}^{-1}$. These values are only 2 to 3 times lower than the self-diffusivity of Sc(III) in water (i.e., $3.44 \times 10^{-8} \mathrm{~m}^{2} \mathrm{~min}^{-1}$ ); this means that resistance to intraparticle diffusion has a weak impact on the mass transfer in the structured material.

\subsubsection{Sorption isotherms}

The sorption isotherms have been determined at $\mathrm{pH}_{0}: 4.5\left(\mathrm{pH}_{\mathrm{eq}}\right.$ : 4.1-4.8) (Fig. 3). The duplicate on Q-APEI series confirms the good experimental reproducibility of Sc(III) sorption. The data of the two series have been mixed to fit experimental profiles with the Langmuir, Freundlich and Sips equations. The isotherms are characterized by a saturation plateau (at $1.02 \mathrm{mmol} \mathrm{Scg}-1$ and $3.84 \mathrm{mmol} \mathrm{Sc} \mathrm{g}^{-1}$ for APEI and Q-APEI sorbents, respectively) reached for a residual Sc(III) concentration close to $10 \mathrm{mmol} \mathrm{Sc} \mathrm{L}^{-1}$. This asymptotic trend means that the power-like function that represents the Freundlich equation is not appropriately designed for fitting Sc(III) sorption isotherm (Table 4) (Fig. AM10, see AMS). On the opposite hand, the Langmuir equation respects the general shape of the isotherm curves: maximum sorption capacities at saturation of the monolayer $\left(\mathrm{q}_{\mathrm{m}, \mathrm{L}}\right)$ are close to the

Table 3

Sc(III) uptake kinetics using APEI and Q-APEI sorbents - Kinetic modeling (experimental conditions: see Fig. 2).

\begin{tabular}{|c|c|c|c|c|}
\hline Model & Parameter & APEI & Q-APEI-1st & Q-APEI-2nd \\
\hline $\mathrm{q}_{\mathrm{eq} \text {, exp. }}$ & $\mathrm{q}_{\mathrm{eq}, \exp .}\left(\mathrm{mmol} \mathrm{Sc} \mathrm{g}{ }^{-1}\right)$ & 0.451 & 1.594 & 1.623 \\
\hline \multirow[t]{3}{*}{ PFORE } & $\mathrm{q}_{\mathrm{eq}, 1}\left(\mathrm{mmol} \mathrm{Sc} \mathrm{g}^{-1}\right)$ & 0.465 & 1.638 & 1.657 \\
\hline & $\mathrm{k}_{1} \times 10^{2}$ & 5.24 & 4.91 & 5.61 \\
\hline & $\mathrm{R}^{2}$ & 0.995 & 0.990 & 0.994 \\
\hline \multirow[t]{3}{*}{ PSORE } & $\mathrm{q}_{\mathrm{eq}, 2}\left(\mathrm{mmol} \mathrm{Sc} \mathrm{g}^{-1}\right)$ & 0.559 & 1.997 & 1.976 \\
\hline & $\mathrm{k}_{2} \times 10^{2}$ & 10.5 & 2.65 & 3.27 \\
\hline & $\mathrm{R}^{2}$ & 0.982 & 0.936 & 0.982 \\
\hline \multirow[t]{2}{*}{ RIDE } & $\mathrm{D}_{\mathrm{e}} \times 10^{8}\left(\mathrm{~m}^{2} \mathrm{~min}^{-1}\right)$ & 1.37 & 1.65 & 1.94 \\
\hline & $\mathrm{R}^{2}$ & 0.985 & 0.974 & 0.983 \\
\hline
\end{tabular}




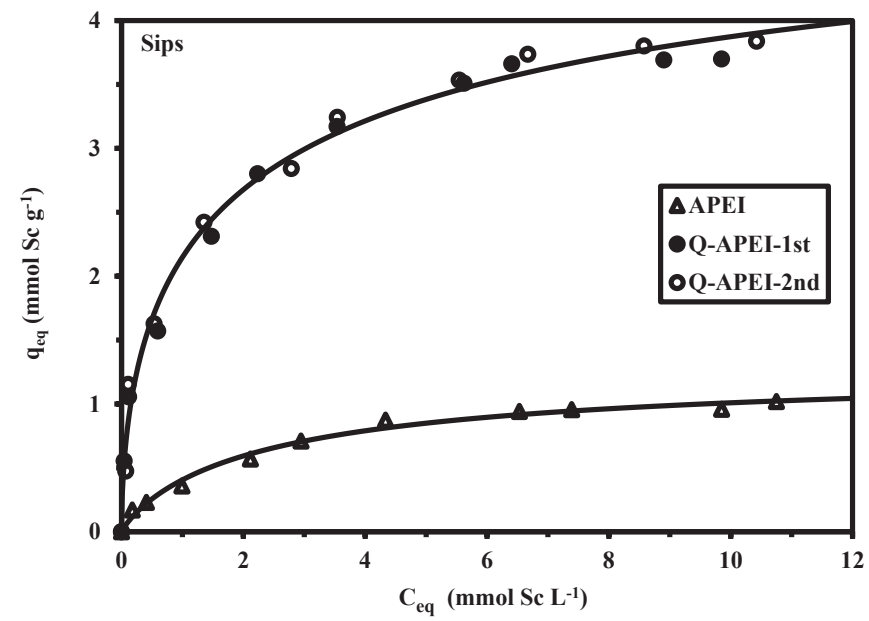

Fig. 3. Sc(III) sorption isotherms for APEI and Q-APEI - Sips model $\left(\mathrm{C}_{0}\right.$ : 0.2-12 mmol Sc L ${ }^{-1}$; SD: $0.3 \mathrm{gL}^{-1}$; $\mathrm{pH}_{0}$ : 4.5; $\mathrm{pH}_{\mathrm{eq}}$ : 4.1-4.8; Temperature: $20 \pm 1{ }^{\circ} \mathrm{C}$; Agitation: $\left.140 \mathrm{rpm}\right)$.

experimental values $\left(\mathrm{q}_{\mathrm{m} \text {,exp }}\right)$ : the values are overestimated by $18 \%$ for APEI and by less than $5 \%$ for Q-APEI. The quaternization strongly increases the maximum sorption capacity but also the affinity coefficient (i.e., b, $\mathrm{L} \mathrm{mmol}^{-1}$ ): the affinity coefficient for APEI is more than doubled for Q-APEI. However, the simulated profiles are failing to fit the part of the curves with the maximum curvature. Obviously, introducing an additional fitting parameter (as in the Sips equation) allows improving the mathematical fit of experimental profiles but at the expense of a decrease in physicochemical meaning. Fig. 3 precisely shows the fit of sorption isotherms with the Sips equation: the simulated curves are perfectly fitting experimental data.

Fig. AM6 (see AMS) shows the speciation diagram of Sc(III) at $\mathrm{pH}$ 4.5 for the whole range of concentration used for Sc(III) sorption isotherm. Though at low metal concentration a wide number of metal species coexist, at higher Sc(III) concentration (above $2 \mathrm{mmol} \mathrm{Sc} \mathrm{L}^{-1}$ ), the predominant species (close to 80\%) is the cationic species $\mathrm{ScSO}_{4}{ }^{+}$; other individual species represent less than $5 \%$.

Table 5 compares the main characteristics for Sc(III) sorption of APEI and Q-APEI sorbents to alternative materials. APEI beads show comparable sorption properties to the most efficient sorbents tested at $\mathrm{pH}$ in the range 4-5.5. The quaternized sorbent (Q-APEI) exhibits outstanding sorption properties with a maximum sorption capacity close to $3.83 \mathrm{mmol} \mathrm{Sc}^{-1}\left(\mathrm{q}_{\mathrm{m}, \mathrm{L}}: 4.0 \mathrm{mmol} \mathrm{Sc}^{-1}\right)$. The sorption isotherm was not carried out at less efficient $\mathrm{pH}$ values (i.e., around $\mathrm{pH}$ 2.5) for effective comparison with, for example, aminomethyl phosphonic-based resin (TP 260) (i.e., $1.71 \mathrm{mmol} \mathrm{Sc}^{-1}$ ) [60]; it is thus difficult concluding on the superiority of this new sorbent. However, Fig. 1 showed that at $\mathrm{pH} 2.5$ the sorption capacity reached $0.4 \mathrm{mmol} \mathrm{Sc} \mathrm{g}^{-1}$ although the metal concentration used was about 10

Table 4

Sc(III) sorption isotherms using APEI and Q-APEI sorbents - Isotherm modeling.

\begin{tabular}{llll}
\hline Model & Parameter & APEI & Q-APEI-1st \\
\hline q & & 1.019 & 3.838 \\
Langmuir exp. & $\mathrm{q}_{\text {eq,exp. }}\left(\mathrm{mmol} \mathrm{sc} \mathrm{g}^{-1}\right)$ & 1.207 & 3.999 \\
& $\mathrm{q}_{\mathrm{m}, \mathrm{L}}\left(\mathrm{mmol} \mathrm{sc}^{-1}\right)$ & 0.492 & 1.257 \\
& $\mathrm{~b}_{\mathrm{L}}\left(\mathrm{L} \mathrm{mol}^{-1}\right)$ & 0.987 & 0.970 \\
Freundlich & $\mathrm{R}^{2}$ & 0.422 & 2.044 \\
& $\mathrm{k}_{\mathrm{F}}$ & 2.530 & 3.378 \\
\multirow{3}{*}{ Sips } & $\mathrm{n}_{\mathrm{F}}$ & 0.956 & 0.970 \\
& $\mathrm{R}^{2}$ & 1.296 & 5.591 \\
& $\mathrm{q}_{\mathrm{m}, \mathrm{S}}\left(\mathrm{mmol} \mathrm{Sc}^{-1}\right)$ & 0.457 & 0.624 \\
& $\mathrm{~b}_{\mathrm{S}}\left(\mathrm{Lmol}^{-1}\right)$ & 1.128 & 1.792 \\
& $\mathrm{n}_{\mathrm{S}}$ & 0.986 & 0.987 \\
\hline
\end{tabular}

times lower than metal concentrations necessary to reach saturation of the sorbent. This is a clear evidence of the promising perspectives opened by this new material.

\subsubsection{Sorption selectivity}

The sorption of Sc(III) was carried out in multi-component solutions containing equimolar concentrations of alkali metal (mono-valent $\mathrm{Na}$ (I)), alkali-earth metal (divalent $\mathrm{Ca}(\mathrm{II})$ and $\mathrm{Mg}(\mathrm{II})$ ) and a representative of rare earth elements (trivalent Sm(III)). Table AM11 (see AMS) summarizes the main physical-chemical characteristics of selected metal ions. The effect of the $\mathrm{pH}_{0}$ was also tested in the range 1.3-5.0 $\left(\mathrm{pH}_{\mathrm{eq}}\right.$ varying between 1.5 and 4.4). The speciation diagrams are represented in Fig. AM11 (see AMS). For $\mathrm{Na}(\mathrm{I}), \mathrm{Mg}(\mathrm{II})$, and $\mathrm{Ca}(\mathrm{II})$ the metal ions predominate as free species (between 65\% and 98\%) and the $\mathrm{pH}$ hardly affects the relative proportions against their sulfate complexes. For Sc(III) and Sm(III), the speciation behavior is substantially different with a predominance of cationic sulfate species (in the range $82-87 \%$ for $\mathrm{Sc}\left(\mathrm{SO}_{4}\right)^{+}$, and $73-77 \%$ for $\mathrm{Sm}\left(\mathrm{SO}_{4}\right)^{+}$).

Fig. AM12 (see AMS) compares the sorption capacities for target metal ions at different selected $\mathrm{pH}$ values. While $\mathrm{Mg}(\mathrm{II}), \mathrm{Sm}(\mathrm{III}), \mathrm{Ca}(\mathrm{II})$, and $\mathrm{Na}(\mathrm{I})$ show similar trends with sorption capacities below $0.2 \mathrm{mmol}$ metal $\mathrm{g}^{-1}$ and limited effect of $\mathrm{pH}$ (except at $\mathrm{pH}$ above 4.3, where a little step is observed), the sorption of Sc(III) shows a continuous increase in sorption capacity with $\mathrm{pH}$ to reach a value up to $0.8 \mathrm{mmol} \mathrm{Sc}^{-1}$.

Fig. AM13 (see AMS) shows the relative fractions of the elements in the sorbent at equilibrium in function of the $\mathrm{pH}$ of the solution, together with the cumulative sorption capacities. Total sorption capacity increases from $0.27 \mathrm{mmolmetal} \mathrm{g}^{-1}$ at $\mathrm{pH} 1.53$ to $1.78 \mathrm{mmol} \mathrm{metal} \mathrm{g}^{-1}$ at $\mathrm{pH} 4.41$.

At $\mathrm{pH}$ 1.53, the predominant species follow the sequence: $\mathrm{Ca}$ (II) $>\mathrm{Sm}$ (III) $>\mathrm{Sc}$ (III) $\gg \mathrm{Na}$ (I) $\gg \mathrm{Mg}$ (II).

At $\mathrm{pH}$ 4.41: the order of affinity is substantially changed: Sc(III) (above $53 \%$ ) $>\mathrm{Sm}(\mathrm{III}) \approx \mathrm{Ca}(\mathrm{II}) \approx \mathrm{Na}(\mathrm{I})>\mathrm{Mg}(\mathrm{II})$.

Sc(III) and Sm(III) belonging to trivalent and Group 3 metals have very similar behavior (consistently with their sulfate association trends), though the sorbent maintains, at moderately acidic $\mathrm{pH}$, a marked preference for $\mathrm{Sc}(\mathrm{III})$. In order to better visualize separation properties, the selectivity coefficient (defined as the ratio of the distribution ratios, $\mathrm{SC}_{\mathrm{m} 1 / \mathrm{m} 2}=\mathrm{D}\left(\mathrm{m}_{1}\right) / \mathrm{D}\left(\mathrm{m}_{2}\right)$ was plotted in function of $\mathrm{pH}_{\mathrm{eq}}$ (Fig. 4), for Sc(III) and for Sm(III) over other metals ( $\mathrm{SC}_{\mathrm{Sc} / \mathrm{m}}$, and $\mathrm{SC}_{\mathrm{Sm} / \mathrm{m}}$, respectively). The sorbent shows similar selectivity trends against the other metals with SC values being relatively stable between $\mathrm{pH} 1.5$ and 3.3 before substantially increasing while $\mathrm{pH}$ rises 4 . The selectivity for $\mathrm{Sc}(\mathrm{III})$ is comparable for $\mathrm{Na}(\mathrm{I}), \mathrm{Ca}(\mathrm{II})$ and $\mathrm{Sm}(\mathrm{III})$ while for $\mathrm{Mg}$ (II) the SC values are shifted by about 10 units. The sorbent is highly selective to $\mathrm{Sc}(\mathrm{III})$ at $\mathrm{pH}$ higher than 4 for $\mathrm{Na}(\mathrm{I}), \mathrm{Ca}(\mathrm{II})$ and $\mathrm{Sm}$ (III) and on a broader $\mathrm{pH}$ range against $\mathrm{Mg}$ (II) (though the selectivity is even more increased at $\mathrm{pH}$ higher than 4). The plots for Sm(III) selectivity against $\mathrm{Sc}(\mathrm{III}), \mathrm{Na}(\mathrm{I}), \mathrm{Ca}(\mathrm{II})$ show a poor effect of $\mathrm{pH}$ and limited separation properties. On the other hand, Q-APEI is selective for $\mathrm{Sm}$ (III) against $\mathrm{Mg}(\mathrm{II})$, especially in acidic solutions.

Table AM12 (see AMS) summarizes the SEM pictures of the surface of Q-APEI beads after processing the sorption test in multicomponent solutions at different $\mathrm{pH}$ values, together with the semi-quantitative EDX analysis of major elements. The topography of the surface is not significantly modified, whatever the $\mathrm{pH}$ and the relative accumulation of metals. The most remarkable variations concern: (a) the significant increase in Sc and Sm contents with pH (especially above $\mathrm{pH} 3$ ), (b) the relative stability of $\mathrm{Ca}, \mathrm{Na}$ and $\mathrm{Mg}$ contents. The contents of $\mathrm{S}$ (for sulfate) and $\mathrm{Cl}$ slightly decreases with $\mathrm{pH}$ increase. This may be explained by a change in the speciation of metal species bound on the sorbent. It is noteworthy that, compared to the contents of these compounds in the as-prepared sorbent, $\mathrm{S}$ fraction substantially increases from $1.84 \mathrm{wt} \%$ to $15.4 \pm 5.1 \mathrm{wt} \%$ (depending on the $\mathrm{pH}$ ). This is due to the $\mathrm{pH}$ control using sulfuric acid and to the sorption of anionic 
Table 5

Comparison of Sc(III) sorption performances for selected sorbents.

\begin{tabular}{|c|c|c|c|c|c|}
\hline Sorbent & $\mathrm{T}_{\mathrm{eq}}(\min )$ & $\mathrm{pH}_{0}$ & $\begin{array}{l}\mathrm{q}_{\mathrm{m}}{ }^{*} \\
\left(\mathrm{mmol} \mathrm{Sc} \mathrm{g}{ }^{-1}\right)\end{array}$ & $\begin{array}{l}\mathrm{b} \\
\left(\mathrm{L} \mathrm{mmol}^{-1}\right)\end{array}$ & Reference \\
\hline Extractant/ionic liquid impregnated resin & 50 & 5.3 & 0.99 & 12.6 & [63] \\
\hline Lysine-modified SBA-15 mesoporous silica & 50 & 5 & 0.78 & - & [64] \\
\hline Extractant-supported resin & 360 & 0.78 & 0.18 & 11.2 & {$[26]$} \\
\hline Aminocarbonylmethylglycine - grafted Purolite A110 & 480 & 3 & 0.28 & 3.10 & {$[23]$} \\
\hline Aminocarbonylmethylglycine -grafted silica & 60 & 3 & 0.21 & 5.26 & {$[23]$} \\
\hline Cellulose-supported silica particles & 50 & 6 & 0.53 & - & {$[65]$} \\
\hline Ionic liquid supported on polymer resin $\left(\mathrm{Cl}^{-}\right.$media) & 90 & 3 & 0.36 & 5.68 & {$[25]$} \\
\hline Ionic liquid supported on polymer resin $\left(\mathrm{NO}_{3}{ }^{-}\right.$media $)$ & 90 & 3 & 0.29 & 10.0 & {$[25]$} \\
\hline Phosphinic-based resin (TP 272) & 720 & 2.5 & 0.24 & 49.2 & {$[60]$} \\
\hline Iminodiacetate resin (TP 209) & 2880 & 2.5 & 0.84 & 1.30 & {$[60]$} \\
\hline Aminomethyl phosphonic-based resin (TP 260) & 2880 & 2.5 & 1.71 & 4.32 & [60] \\
\hline Mesoporous silica (SBA-15) & 240 & 3 & 0.025 & 116.3 & [66] \\
\hline Carbon nanotubes & 240 & 2 & 0.93 & - & [67] \\
\hline MTM-functionalized silica & 300 & 4 & 0.54 & 1.35 & {$[68]$} \\
\hline Extractant-impregnated macroporous silica & 360 & $5 \mathrm{M} \mathrm{H}_{2} \mathrm{SO}_{4}$ & 0.30 & 9.97 & {$[69]$} \\
\hline Binary extractant-impregnated synthetic resin & 60 & 2.75 & 1.07 & 0.019 & {$[27]$} \\
\hline Oxidized carbon nanotubes & 30 & 4 & 0.95 & - & {$[20]$} \\
\hline Algal/PAN sorbent & 1440 & 5 & 1.49 & - & [19] \\
\hline APEI & 90 & 4.5 & 1.21 & 0.49 & This work \\
\hline Q-APEI & 90 & 4.5 & 4.00 & 1.26 & This work \\
\hline
\end{tabular}

*Sorption capacity at monolayer saturation (Langmuir model) or maximum sorption capacity; -: not documented.
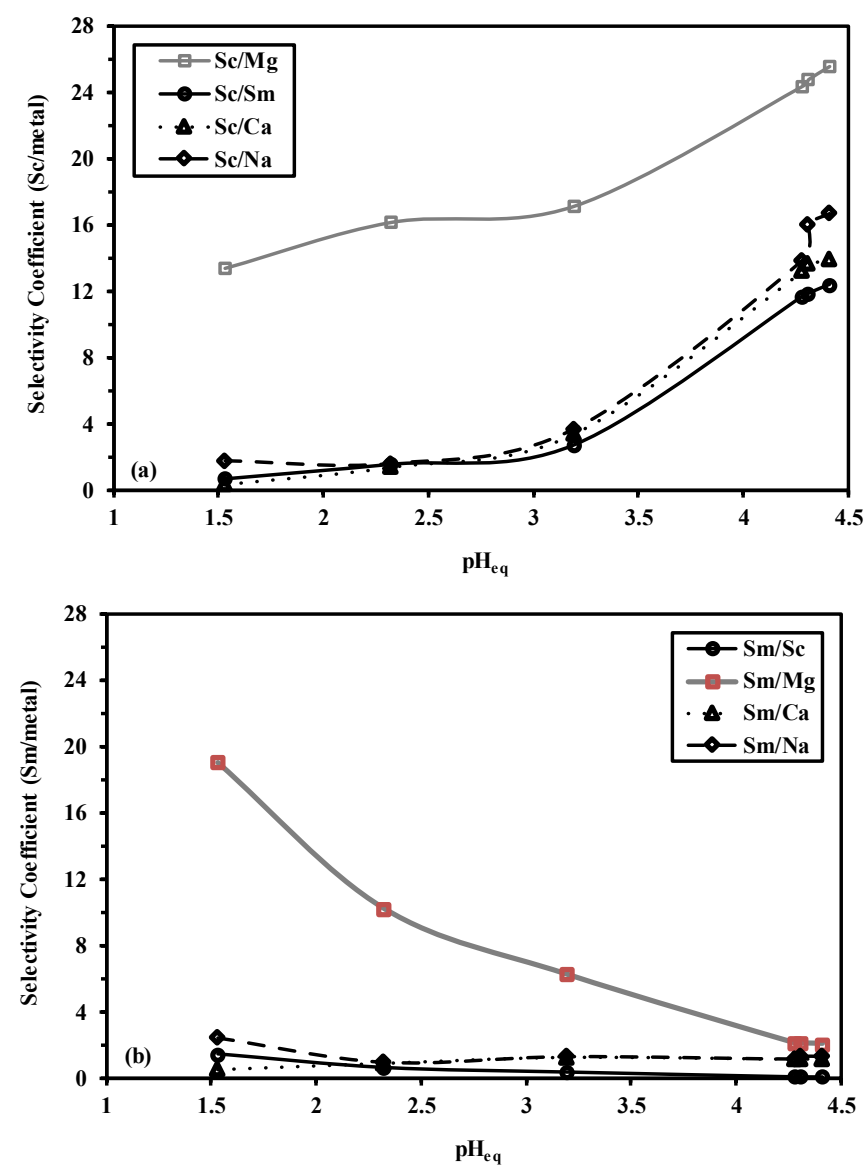

Fig. 4. Effect of $\mathrm{pH}$ on: (a) $\mathrm{Sc}(\mathrm{III})$ sorption selectivity against $\mathrm{Mg}(\mathrm{II}), \mathrm{Sm}(\mathrm{III}), \mathrm{Ca}$ (II) and $\mathrm{Na}(\mathrm{I})$ and (b) $\mathrm{Sm}$ (III) sorption selectivity against $\mathrm{Mg}(\mathrm{II}), \mathrm{Sc}(\mathrm{III}), \mathrm{Ca}(\mathrm{II})$ and $\mathrm{Na}(\mathrm{I})\left(\mathrm{C}_{0}: 1.54 \pm 0.04 \mathrm{mmol}\right.$ metal L $^{-1}$; SD: $0.125 \mathrm{~g} \mathrm{~L}^{-1}$; Temperature: $20 \pm 1{ }^{\circ} \mathrm{C}$; Agitation: $140 \mathrm{rpm}$; Time: $48 \mathrm{~h}$ ).

scandium sulfate species. On the opposite hand, chloride content decreases from $7.47 \mathrm{wt} \%$ on Q-APEI to $1.3 \pm 0.8 \mathrm{wt} \%$ after metal sorption. This is correlated to the ion-exchange of the counter anion on protonated PEI reactive groups (and quaternized sites) with anionic scandium (and samarium) sulfate species.

\subsubsection{Metal desorption and Q-APEI sorbent recycling}

The effect of $\mathrm{pH}$ on metal sorption proved that the sorbent has a poor affinity for $\mathrm{Sc}(\mathrm{III})$ in acidic solutions. This is a first indication that acidic solutions may be efficient for desorbing the metal from loaded sorbent: hydrochloric acid was selected for Sc(III) elution. The APEI material involves a double crosslinking mode: (a) glutaraldehyde/ amine groups (from PEI), and (b) the ionotropic gelation of carboxylic groups (on alginate-based materials) with $\mathrm{Ca}(\mathrm{II})$. In order to reinforce the stability of the material under strong desorbing conditions $\mathrm{CaCl}_{2}$ was added to the eluent; in addition, $\mathrm{Ca}$ (II) ions may contribute to improve desorption through ion-exchange effect. A $0.5 \mathrm{M} \mathrm{HCl} / \mathrm{CaCl}_{2}$ solution was used for Sc(III) desorption. The choice of eluent that contains $\mathrm{HCl}$ for metal release and also calcium chloride for maintaining the hydrogel structure (ionotropic gelation of carboxylic groups on alginate with calcium) results from a compromise between elution efficiency and sorbent stability. Therefore, a part of calcium remains bound to the sorbent after elution. This contributes to minimize the contamination of Sc(III) eluate with calcium. For final valorization, Sc (III) can be precipitated as $\mathrm{Sc}(\mathrm{OH})_{3}$, at $\mathrm{pH} 4-5$, using $2-5 \mathrm{M} \mathrm{NaOH}$ solution [61]. Calcium is not supposed to precipitate under these conditions; combined to Ca binding to alginate (and limited concentration), the contamination of the scandium hydroxide cake is considered negligible. In addition, for further purification of the scandium salt, it is possible dissolving the precipitate with sulfuric or hydrochloric acid before precipitating $\mathrm{Sc}$ with oxalic acid to form $\mathrm{Sc}_{2}\left(\mathrm{C}_{2} \mathrm{O}_{4}\right)_{3}$. The oxalate salt is finally calcinated to form pure $\mathrm{Sc}_{2} \mathrm{O}_{3}$ [22].

Fig. AM14 (see AMS) shows the desorption kinetics of Sc(III) from Q-APEI beads (collected from kinetic experiments). The desorption is little faster than the sorption: complete desorption occurs within 20-30 min of contact (compared with 60-90 min for sorption). The PFORE and PSORE models have been adapted simulating desorption kinetics [62]. The solid lines in Fig. AM14 represent the PFORE fits of experimental profiles; Table AM3 (see AMS) summarizes the values of relevant parameters. The determination coefficients are higher for PFORE than for PSORE; however, the PFORE model fails to fit the intermediary stage (corresponding to the highest curvature, at around 15 min of contact) and the model is more appropriate for simulating QAPEI sorbent than APEI sorbent.

Table 6 compares sorption and desorption efficiencies for five successive cycles of re-use. A little decrease in sorption efficiency is observed: $83.5 \%$ at the fifth cycle, compared with initial value: $88.1 \%$ (variation at the last cycle is less than $6 \%$ ). On the other hand, the 
Table 6

Sorption and desorption cycles for Sc(III) recovery using Q-APEI.

\begin{tabular}{lllll}
\hline \multirow{2}{*}{ Cycle } & \multicolumn{2}{l}{ Sorption efficiency (\%) } & \multicolumn{2}{l}{ Desorption efficiency (\%) } \\
\cline { 2 - 5 } & Average & St. Dev. & Average & St. Dev. \\
\hline$\# 1$ & 88.1 & 1.7 & 100.0 & 0.1 \\
$\# 2$ & 87.1 & 0.8 & 99.4 & 0.4 \\
$\# 3$ & 85.9 & 1.0 & 99.9 & 1.0 \\
$\# 4$ & 84.9 & 1.0 & 100.1 & 0.3 \\
$\# 5$ & 83.5 & 1.0 & 99.6 & 0.7 \\
\hline
\end{tabular}

desorption efficiency ranges between $99.4 \%$ and $100 \%$ along the five cycles: Sc(III) can be readily and stably desorbed using $0.5 \mathrm{M} \mathrm{HCl} / \mathrm{CaCl}_{2}$ solutions. The sorbent is remarkably stable, at least for five cycles.

This is supported by the analysis of the sorbent after five cycles of re-use. Some shifts are observed on FTIR spectra (Table AM6 and Fig. AM2, see AMS); however, the spectra are very similar after the first desorption and the fifth desorption steps. Sc(III) desorption was also studied through XPS analysis (Tables AM8-10): the most substantial changes on typical signals of Q-APEI sorbent (initial product) and operation sorption/desorption cycle are appearing on $\mathrm{C} 1 \mathrm{~s}$. The chemical environments of $\mathrm{O} 1 s$ and $\mathrm{N} 1 s$ are relatively well maintained after operating the sorbent. The desorption protonates the sorbent, which also binds calcium (ion-exchange) (Table AM5, see AMS): this explains the changes in the FTIR; the next cycles do not change the physicochemical characteristics of the material. This is also consistent with the conclusions reported at Section 3.1.2. (Table AM4, see AMS).

\section{Industrial application on effluent issued from red mud}

The red mud industrial solution (after being diluted 4 times with demineralized water, RMIS) was controlled at different $\mathrm{pH}$ values ranging between 1 and 10. The adjustment of $\mathrm{pH}$ strongly influenced the composition of the solution with strong precipitation occurring at $\mathrm{pH}$ higher than 2 or 3. Fig. AM15 (see AMS) shows the precipitation profiles: titanium and aluminum have very sharp precipitation with $\mathrm{pH}_{50}$ (pH for $50 \%$ precipitation) close to 2.60, and 3.24 respectively; at $\mathrm{pH}$ higher than 4 , the metal ions are almost completely precipitated. For the elements of the group constituted of $\mathrm{Si}, \mathrm{Fe}$ and $\mathrm{Sc}$, the precipitation begins at $\mathrm{pH}$ close to 3 and progressively increases up to equilibrium $\mathrm{pH}$ close to 6 , before stabilizing (with a precipitation yield in the range 65-80\%, except for Fe that is fully precipitated at $\mathrm{pH}$ 6.13). The $\mathrm{pH}_{50}$ increases following the sequence 4.02 (for $\mathrm{Fe}$ ), 4.30 (for $\mathrm{Si}$ ) and 5.14 (for Sc). For zirconium, the precipitation begins at $\mathrm{pH} 2$ and then progressively increases up to 6.13; the $\mathrm{pH}_{50}$ is close to 4.04. Table AM13 (see AMS) shows the concentrations of major elements in (diluted) red mud industrial solution after controlling the $\mathrm{pH}$ to different values. This characterization is completed by Table AM14 (see AMS) that shows the composition (major elements) of the precipitates (semi-quantitatively analyzed by EDX): the precipitates are mainly constituted of iron hydroxide, silica hydroxide with traces of aluminum hydroxide (at acidic $\mathrm{pH}$ values).

Fig. AM16 (see AMS) shows the molar distribution of selected metals in the solution after $\mathrm{pH}$ control: iron represents between $73 \%$ and $98 \%$ (maximum in the $\mathrm{pH}$ range 4-6). At $\mathrm{pH}$ below 4, predominant elements are $\mathrm{Al}$ (up to $6 \%$ ) $>\mathrm{Ti}$ (up to $4 \%$ ) $>\mathrm{Si}$ (around $0.6 \%$ ), while at $\mathrm{pH}$ higher than 6 , the main elements are $\mathrm{Ti}$ (up to $12 \%$ ) $\approx \mathrm{Si}$ (up to $10 \%)>\mathrm{Al}$ (up to $3 \%$ ) > $\mathrm{Zr}$ and Sc (up to $0.5 \%$ ). Obviously, zirconium and scandium have molar concentrations much lower, by 2 to 3 orders of magnitude than those of $\mathrm{Fe}, \mathrm{Al}$ and $\mathrm{Ti}$, which are the most representative metals in RMIS. This may strongly affect the effect of competitor ions on Sc(III) sorption. Table AM15 (see AMS) shows that titanium is only detected at the surface of the sorbent at the lowest $\mathrm{pH}$ (i.e., $\mathrm{pH} 2$ ). In addition, a high proportion of iron is detected on Q-APEI (especially at acidic $\mathrm{pH}$ : $30-34 \mathrm{wt} \%$, while it tends to decrease at alkaline $\mathrm{pH}$ ); this is probably associated with a dual mechanism of sorption and local precipitation. Scandium is present at the different $\mathrm{pH}$ values (with highest contents in the range of $\mathrm{pH} 4-8$ : between 2.2 and $3.1 \% \mathrm{wt} \%$ ), probably associated to sulfate anions because of the high contents of $\mathrm{S}$ element (in the range 11-26\%; due to sulfate complexation of other metal ions and to direct sulfate binding on protonated amine groups).

The removal efficiency is reported in Fig. 5. Scandium(III) is quantitatively removed on the whole range of $\mathrm{pH}$. For Si(IV) and $\mathrm{Zr}(\mathrm{IV})$, the sorption increases with $\mathrm{pH}$ but reaches a plateau at $\mathrm{pH}$ higher than 3-3.5 (complete removal of silica and removal yield stabilized around $85 \%$ for zirconium). The sorption of titanium and aluminum is negligible between $\mathrm{pH} 1$ and 2-3 before strongly increasing and reaching a plateau close to 75-85\%. In the case of iron, the sorption begins at higher $\mathrm{pH}$ value (i.e., $\mathrm{pH} 6$ ); at $\mathrm{pH} 8$, the removal yield reaches $93 \%$ : this is probably due to the combination of sorption and precipitation phenomena.

Actually, the sorption capacities for Zr(IV) and Sc(III) are very low (Fig. AM17, see AMS) due to their very low levels in the RMIS and the strong excesses of iron, aluminum, silica and titanium (Table AM13, see AMS). However, despite the strong sorption of highly concentrated metal ions, the sorption of Sc(III) is quantitative (higher than 96\%) on the whole $\mathrm{pH}$ range: removal yield exceeds $98 \%$ for $\mathrm{pH}$ below 3 and tends to decrease with $\mathrm{pH}$ increase.

Fig. AM18 (see AMS) compares the selectivity coefficients for Sc over the five other elements, at different contact times (20,30 and $48 \mathrm{~h}$ ). Regardless of the competitor metal, the highest selectivity coefficients are obtained at acidic $\mathrm{pH}$. The optimum $\mathrm{pH}$ for highest selectivity is $\mathrm{pH} 1$ against $\mathrm{Si}(\mathrm{IV}), \mathrm{Al}(\mathrm{III})$, and $\mathrm{Fe}$ and at $\mathrm{pH} 2$ against $\mathrm{Zr}(\mathrm{IV})$ and $\mathrm{Ti}(\mathrm{III})$. Increasing the $\mathrm{pH}$ above 3 , progressively decreases the selectivity for scandium over other metals. At $\mathrm{pH}$ higher than 3 , the selectivity coefficients are strongly depressed (being below 5); this is correlated to the $\mathrm{pH}$ where was observed the first precipitation step (Fig. AM14, see AMS). For Fe element, the selectivity coefficient for Sc drastically decreases until pH 3 , stabilizes between $\mathrm{pH} 3$ and $\mathrm{pH}$ 6, and then drastically decreases below 3 . It is noteworthy that the highest selectivity coefficients follow the sequence: $\mathrm{Fe} \quad(\approx 7500) \gg \mathrm{Al}(\mathrm{III}) \quad(\approx 1700)>\mathrm{Ti}(\mathrm{IV}) \quad(\approx 1160) \gg \mathrm{Zr}(\mathrm{IV})$ $(\approx 70)>\mathrm{Si}(\mathrm{IV})(\approx 44)$. The strong excess of $\mathrm{Fe}, \mathrm{Al}$ and $\mathrm{Ti}$ may explain that the enrichment factor (associated with the distribution coefficient) is lower for these elements compared to less concentrated elements (Fig. 6); in addition to the proper selectivity of the sorbent for Sc(III). In most cases, the optimum contact time is obtained at $30 \mathrm{~h}$.

Taking into account the strong decrease in metal concentrations at $\mathrm{pH}$ higher than 3 , it is more appropriate recovering scandium at $\mathrm{pH}$ 1-2: the abatement of iron (lower than $2 \%$ ), titanium (lower than 9\%) and aluminum (lower than 16\%) weakly impact Sc(III) sorption despite the great excesses of these competitor ions. The recoveries of zirconium and silica reach around $60 \%$ and $71-78 \%$, respectively.

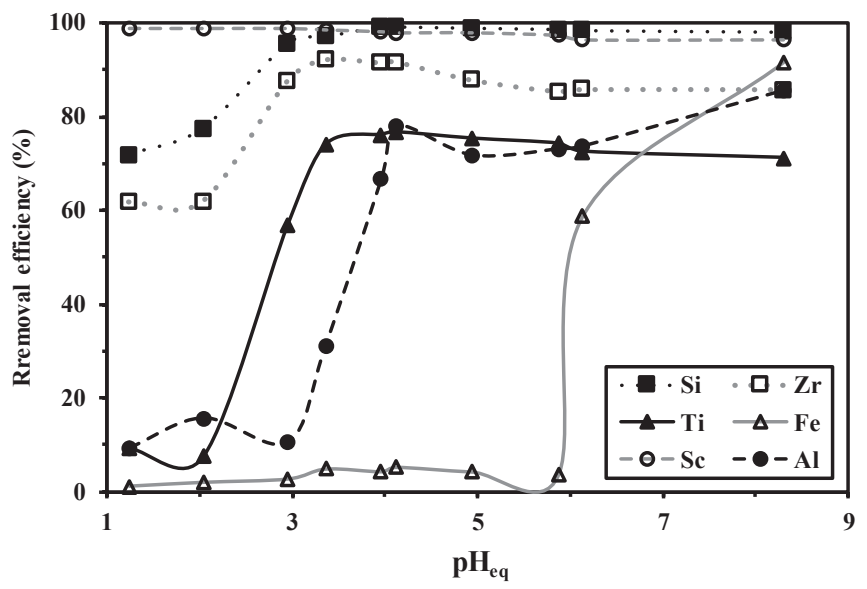

Fig. 5. Effect of $\mathrm{pH}$ on removal efficiency of selected metals from red mud industrial solution (RMIS) using Q-APEI (SD: $0.6 \mathrm{gL}^{-1}$; Temperature: $20 \pm 1{ }^{\circ} \mathrm{C}$; Agitation: $140 \mathrm{rpm}$; contact time: $30 \mathrm{~h}$ ). 


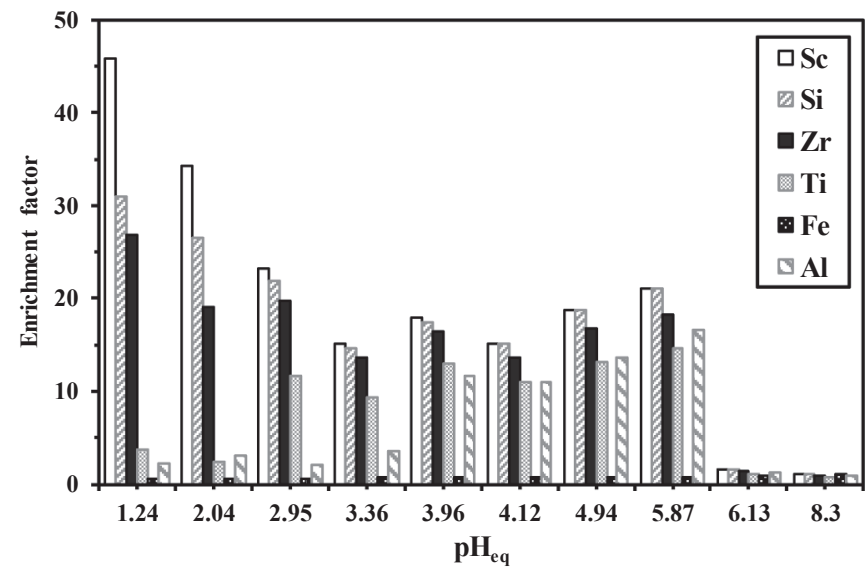

Fig. 6. Effect of $\mathrm{pH}$ on the enrichment factor of selected metals after sorption on Q-APEI from RMIS (SD: $0.6 \mathrm{~g} \mathrm{~L}^{-1}$; Temperature: $20 \pm 1{ }^{\circ} \mathrm{C}$; Agitation: $140 \mathrm{rpm}$; contact time: $30 \mathrm{~h}$ ).

The quaternized sorbent (Q-APEI) is not selective for the treatment of RMIS because of multi-metal sorption and huge excess of elements such as iron, aluminum or titanium; however, despite their huge excess, the sorption of scandium is almost quantitative. The separation of scandium from multi-metal loaded sorbent was not investigated, but this could be a complementary method for improving the separation of $\mathrm{Sc}(\mathrm{III})$ from predominating metal ions playing with desorption and selective precipitations of target metals.

\section{Conclusion}

The quaternization of algal/PEI beads allows significantly increasing the sorption of $\mathrm{Sc}$ (III) from slightly acidic solutions. The functionalization increases the $\mathrm{pH}_{\mathrm{PZC}}$ of the sorbent (from 4.9 to 6.8). The sorption capacity increases with $\mathrm{pH}$ and reaches up to $3.8 \mathrm{mmol} \mathrm{Sc}^{-1}$. This makes the sorbent one of the most efficient sorbent for Sc(III) binding reported in the literature. The equations of Langmuir and Sips fit well isotherm profiles. The analysis of textural properties show a relatively porous structure (specific surface area reaches up to $34 \mathrm{~m}^{2} \mathrm{~g}^{-1}$ ) with meso-pores representing a volume of $0.18 \mathrm{~cm}^{3} \mathrm{~g}^{-1}$. This may explain the efficient mass transfer and the equilibrium time that does not exceed 60-90 min: the uptake kinetics are well fitted by the pseudo-first order rate equation and the Crank equation (for the resistance to intraparticle diffusion). However, the relatively high diffusion coefficient (compared with selfdiffusivity of Sc(III) in water) demonstrates that the influence of resistance to diffusion is not critical. The sorbent is highly selective at $\mathrm{pH}$ 4.5 for Sc(III) over alkali ( $\mathrm{Na}(\mathrm{I})$ ), and alkali-earth (Ca(II) and $\mathrm{Mg}(\mathrm{II})$ ) elements and trivalent metal ions (i.e., Sm(III)) while processing sorption from multi-metal solutions containing equimolar concentrations. Though the sorbent cannot be considered selective for Sc(III), when applied to complex industrial solutions containing huge concentrations of $\mathrm{Fe}$, Ti and Al (240 $\mathrm{mg} \mathrm{Al} \mathrm{L}^{-1}$, $300 \mathrm{mg} \mathrm{Ti} \mathrm{L}^{-1}$, and $7281 \mathrm{mg} \mathrm{Fe} \mathrm{L}^{-1}$ ) Q-APEI can quantitatively recover $\mathrm{Sc}$ (at concentration as low as $1.5 \mathrm{mg} \mathrm{Sc} \mathrm{L}^{-1}$ ). The desorption of scandium from loaded sorbent is fast and quantitative (total desorption achieved within $30-40 \mathrm{~min}$ ) using $0.5 \mathrm{M} \mathrm{HCl} / \mathrm{CaCl}_{2}$ solution. The sorbent can be recycled for a minimum of five cycles with limited decrease in sorption (less than $8 \%$ ) and desorption performance (which remains quantitative along the five cycles). The presence of calcium chloride in the eluent contributes to the stabilization of the sorbent.

The chemical modification and the modes of interactions (involving carboxylic and amine groups) have been characterized together with the proper chemical structure of the sorbents using FTIR spectroscopy and XPS spectrometry. These methods were also used for characterizing the chemical changes of the sorbent along the different use steps (sorption, desorption) and life cycle (after five cycles of sorption and desorption). Although some changes are observed, it appears that the material is stable enough for being successfully re-used for a number of cycles.

\section{Declaration of Competing Interest}

The authors declare that they have no known competing financial interests or personal relationships that could have appeared to influence the work reported in this paper.

\section{Acknowledgements}

The authors thank the TYSP program (Talented Young Scientists Program, China) for the fellowship of M.F.H and the Science and Technology Major Project (AA17204100) of Guangxi,China. The authors also acknowledge the financial support of Institut Français d'Egypte, (French Government, France) and Science and Technology Development Fund (Egyptian Academy of Science and Technology, Egypt).

\section{Appendix A. Supplementary data}

Supplementary data to this article can be found online at https:// doi.org/10.1016/j.cej.2019.123210.

\section{References}

[1] BRGM, Fiche de Synthèse sur la criticité des Matières Premières Minérales - Le Scandium - Novembre 2017, in: BRGM (Ed.), BRGM, Orléans, France, 2017, pp. 6.

[2] J.H. Wynne, J.L. Buckley, C.E. Coumbe, J.P. Phillips, S. Stevenson, Reducing hazardous material and environmental impact through recycling of scandium nanomaterial waste, J. Environ. Sci. Health Part A 43 (2008) 357-360.

[3] C. Ruiz Canovas, F. Macias, R. Perez Lopez, J. Miguel Nieto, Mobility of rare earth elements, yttrium and scandium from a phosphogypsum stack: Environmental and economic implications, Sci. Total Environ. 618 (2018) 847-857.

[4] N. Zhang, H.-X. Li, X.-M. Liu, Recovery of scandium from bauxite residue-red mud: a review, Rare Met. 35 (2016) 887-900.

[5] K. Zhou, C. Teng, X. Zhang, C. Peng, W. Chen, Enhanced selective leaching of scandium from red mud, Hydrometallurgy 182 (2018) 57-63.

[6] M. Ochsenkuehn-Petropoulou, L.-A. Tsakanika, T. Lymperopoulou, K.-M. Ochsenkuehn, K. Hatzilyberis, P. Georgiou, C. Stergiopoulos, O. Serifi, F. Tsopelas, Efficiency of sulfuric acid on selective scandium leachability from bauxite residue, Metals 8 (2018) Art. $\mathrm{N}^{\circ} 915$.

[7] C.R. Borra, J. Mermans, B. Blanpain, Y. Pontikes, K. Binnemans, T. Van Gerven, Selective recovery of rare earths from bauxite residue by combination of sulfation, roasting and leaching, Miner. Eng. 92 (2016) 151-159.

[8] Z. Liu, H. Li, Metallurgical process for valuable elements recovery from red mud - a review, Hydrometallurgy 155 (2015) 29-43.

[9] R.M. Rivera, B. Xakalashe, G. Ounoughene, K. Binnemans, B. Friedrich, T. Van Gerven, Selective rare earth element extraction using high-pressure acid leaching of slags arising from the smelting of bauxite residue, Hydrometallurgy 184 (2019) $162-174$.

[10] C.R. Borra, Y. Pontikes, K. Binnemans, T. Van Gerven, Leaching of rare earths from bauxite residue (red mud), Miner. Eng. 76 (2015) 20-27.

[11] B. Yagmurlu, C. Dittrich, B. Friedrich, Effect of aqueous media on the recovery of scandium by selective precipitation, Metals 8 (2018).

[12] R.P. Narayanan, N.K. Kazantzis, M.H. Emmert, Selective process steps for the recovery of scandium from Jamaican bauxite residue (Red Mud), ACS Sustain. Chem. Eng. 6 (2018) 1478-1488.

[13] D. Avdibegovic, B. Yagmurlu, C. Dittrich, M. Regadio, B. Friedrich, K. Binnemans, Combined multi-step precipitation and supported ionic liquid phase chromatography for the recovery of rare earths from leach solutions of bauxite residues, Hydrometallurgy 180 (2018) 229-235.

[14] Q. Ye, G.H. Li, B.N. Deng, J. Luo, M.J. Rao, Z.W. Peng, Y.B. Zhang, T. Jiang, Solvent extraction behavior of metal ions and selective separation $\mathrm{Sc}^{3+}$ in phosphoric acid medium using P204, Sep. Purif. Technol. 209 (2019) 175-181.

[15] A.G.O. Souza, P. Aliprandini, D.C.R. Espinosa, J.A.S. Tenorio, Scandium extraction from nickel processing waste using Cyanex 923 in sulfuric medium, JOM 71 (2019) 2003-2009.

[16] M. Sharaf, W. Yoshida, F. Kubota, M. Goto, Selective extraction of scandium by a long alkyl chain carboxylic acid/organophosphonic ester binary extractant, Solvent Extr. Ion Exch. 36 (2018) 647-657.

[17] A.A. Korenevsky, V.V. Sorokin, G.I. Karavaiko, Biosorption of rare earth elements, in: R. Amils, A. Ballester (Eds.), Process Metallurgy, Elsevier, 1999, pp. 299-306.

[18] Y. Hosomomi, Y. Baba, F. Kubota, N. Kamiya, M. Goto, Biosorption of rare earth elements by Escherichia coli, J. Chem. Eng. Jpn. 46 (2013) 450-454.

[19] D.L. Ramasamy, S. Porada, M. Sillanpaa, Marine algae: a promising resource for the selective recovery of scandium and rare earth elements from aqueous systems, Chem. Eng. J. 371 (2019) 759-768.

[20] K. Kilian, K. Pyrzynska, M. Pegier, Comparative study of Sc(III) sorption onto carbon-based materials, Solvent Extr. Ion Exch. 35 (2017) 450-459. 
[21] G. Zhou, Q. Li, P. Sun, W. Guan, G. Zhang, Z. Cao, L. Zeng, Removal of impurities from scandium chloride solution using 732-type resin, J. Rare Earths 36 (2018) 311-316.

[22] X. Zhu, W. Li, S. Tang, M. Zeng, P. Bai, L. Chen, Selective recovery of vanadium and scandium by ion exchange with D201 and solvent extraction using P507 from hydrochloric acid leaching solution of red mud, Chemosphere 175 (2017) 365-372.

[23] Z. Zhao, Y. Baba, W. Yoshida, F. Kubota, M. Goto, Development of novel adsorbent bearing aminocarbonylmethylglycine and its application to scandium separation, J. Chem. Technol. Biotechnol. 91 (2016) 2779-2784.

[24] N. Nghiem Van, A. Iizuka, E. Shibata, T. Nakamura, Study of adsorption behavior of a new synthesized resin containing glycol amic acid group for separation of scandium from aqueous solutions, Hydrometallurgy 165 (2016) 51-56.

[25] D. Avdibegovic, M. Regadio, K. Binnemans, Recovery of scandium(III) from diluted aqueous solutions by a supported ionic liquid phase (SILP), RSC Adv. 7 (2017) 49664-49674.

[26] H. Cui, J. Chen, H. Li, D. Zou, Y. Liu, Y. Deng, High-performance polymer-supported extractants with phosphonate ligands for scandium(III) separation, AlChE J. 62 (2016) 2479-2489.

[27] M. Sharaf, W. Yoshida, F. Kubota, M. Goto, A novel binary-extractant-impregnated resin for selective recovery of scandium, J. Chem. Eng. Jpn. 52 (2019) 49-55.

[28] S. Wang, T. Vincent, C. Faur, E. Rodriguez-Castellon, E. Guibal, A new method for incorporating polyethyleneimine (PEI) in algal beads: high stability as sorbent for palladium recovery and supported catalyst for nitrophenol hydrogenation, Mater. Chem. Phys. 221 (2019) 144-155.

[29] S. Lu, L. Chen, M.F. Hamza, C. He, X. Wang, Y. Wei, E. Guibal, Amidoxime functionalization of a poly(acrylonitrile)/silica composite for the sorption of Ga(III) application to the treatment of Bayer liquor, Chem. Eng. J. 368 (2019) 459-473.

[30] M.F. Hamza, Y. Wei, H.I. Mira, A.A.H. Abdel-Rahman, E. Guibal, Synthesis and adsorption characteristics of grafted hydrazinyl amine magnetite-chitosan for $\mathrm{Ni}(\mathrm{II})$ and $\mathrm{Pb}(\mathrm{II})$ recovery, Chem. Eng. J. 362 (2019) 310-324.

[31] Y.S. Ho, G. McKay, Pseudo-second order model for sorption processes, Process. Biochem. 34 (1999) 451-465.

[32] J. Crank, The Mathematics of Diffusion, second. ed., Oxford University Press, Oxford, U.K., 1975, p. 414.

[33] C. Tien, Adsorption Calculations and Modeling, Butterworth-Heinemann, Newton, MA, 1994, p. 243.

[34] D. Manns, M. Nielsen, A. Bruhn, B. Saake, A. Meyer, Compositional variations of brown seaweeds Laminaria digitata and Saccharina latissima in Danish waters, J. Appl. Phycol. 29 (2017) 1493-1506.

[35] A. Deepatana, J.A. Tang, M. Valix, Comparative study of chelating ion exchange resins for metal recovery from bioleaching of nickel laterite ores, Miner. Eng. 19 (2006) 1280-1289.

[36] O.I. Shchukina, A.V. Zatirakha, A.S. Uzhel, A.D. Smolenkov, O.A. Shpigun, Novel polymer-based anion-exchangers with covalently-bonded functional layers of quaternized polyethyleneimine for ion chromatography, Anal. Chim. Acta 964 (2017) $187-194$.

[37] R. Rodriguez-Dorado, C. Lopez-Iglesias, C.A. Garcia-Gonzalez, G. Auriemma, R.P. Aquino, P. Del Gaudio, Design of aerogels, cryogels and xerogels of alginate: effect of molecular weight, gelation conditions and drying method on particles' micromeritics, Molecules 24 (2019).

[38] I. Preibisch, P. Niemeyer, Y. Yusufoglu, P. Gurikov, B. Milow, I. Smirnova, Polysaccharide-based aerogel bead production via jet cutting method, Materials 11 (2018).

[39] F. Wu, J. Li, Y. Tian, Y. Su, J. Wang, W. Yang, N. Li, S. Chen, L. Bao, 3D coral-like nitrogen-sulfur co-doped carbon-sulfur composite for high performance lithiumsulfur batteries, Sci. Rep. 5 (2015).

[40] C. Doroftei, L. Leontie, Synthesis and characterization of some nanostructured composite oxides for low temperature catalytic combustion of dilute propane, RSC Adv. 7 (2017) 27863-27871.

[41] B. Jurado-Lopez, R.S. Vieira, R.B. Rabelo, M.M. Beppu, J. Casado, E. RodriguezCastellon, Formation of complexes between functionalized chitosan membranes and copper: a study by angle resolved XPS, Mater. Chem. Phys. 185 (2017) 152-161.

[42] Y.B. Sun, X.X. Wang, C.C. Ding, W.C. Cheng, C.L. Chen, T. Hayat, A. Alsaedi, J. Hu, X.K. Wang, Direct synthesis of bacteria-derived carbonaceous nanofibers as a highly efficient material for radionuclides elimination, ACS Sustain. Chem. Eng. 4 (2016) $4608-4616$.

[43] M.C. Ortega-Liebana, N.X. Chung, R. Limpens, L. Gomez, J.L. Hueso, J. Santamaria, T. Gregorkiewicz, Uniform luminescent carbon nanodots prepared by rapid pyrolysis of organic precursors confined within nanoporous templating structures, Carbon 117 (2017) 437-446.

[44] Y.W. Zhang, R. Si, C.S. Liao, C.H. Yan, Facile alcohothermal synthesis, size-dependent ultraviolet absorption, and enhanced CO conversion activity of ceria nanocrystals, J. Phys. Chem. B 107 (2003) 10159-10167.

[45] E.O. Lopez, A.L. Rossi, B.S. Archanjo, R.O. Ospina, A. Mello, A.M. Rossi, Crystalline nano-coatings of fluorine-substituted hydroxyapatite produced by magnetron sputtering with high plasma confinement, Surf. Coat. Technol. 264 (2015) 163-174.

[46] M.A.M. Khan, W. Khan, M. Ahamed, A.N. Alhazaa, Microstructural properties and enhanced photocatalytic performance of $\mathrm{Zn}$ doped $\mathrm{CeO}_{2}$ nanocrystals, Sci. Rep. 7 (2017).

[47] K. Yang, L. Zhong, R. Guan, M. Xiao, D. Han, S. Wang, Y. Meng, Carbon felt interlayer derived from rice paper and its synergistic encapsulation of polysulfides for lithium-sulfur batteries, Appl. Surf. Sci. 441 (2018) 914-922.

[48] F. Wang, H. Li, Q. Liu, Z. Li, R. Li, H. Zhang, L. Liu, G.A. Emelchenko, J. Wang, A graphene oxide/amidoxime hydrogel for enhanced uranium capture, Sci. Rep. 6 (2016).

[49] S.J. Yuan, F.J. Xu, E.T. Kang, S.O. Pehkonen, Modification of surface-oxidized copper alloy by coupling of viologens for inhibiting microbiologically influenced corrosion, J. Electrochem. Soc. 154 (2007) C645-C657.

[50] J. Baltrusaitis, P.M. Jayaweera, V.H. Grassian, XPS study of nitrogen dioxide adsorption on metal oxide particle surfaces under different environmental conditions, Phys. Chem. Chem. Phys. 11 (2009) 8295-8305.

[51] L. Qie, W. Chen, X. Xiong, C. Hu, F. Zou, P. Hu, Y. Huang, Sulfur-doped carbon with enlarged interlayer distance as a high-performance anode material for sodium-ion batteries, Adv. Sci. 2 (2015).

[52] A. Liu, G. Liu, H. Zhu, H. Song, B. Shin, E. Fortunato, R. Martins, F. Shan, Waterinduced scandium oxide dielectric for low-operating voltage $\mathrm{n}$ - and p-type metaloxide thin-film transistors, Adv. Funct. Mater. 25 (2015) 7180-7188.

[53] P. Dos Santos Araujo, G.B. Belini, G.P. Mambrini, F.M. Yamaji, W.R. Waldman, Thermal degradation of calcium and sodium alginate: a greener synthesis towards calcium oxide micro/nanoparticles, Int. J. Biol. Macromol. (2019).

[54] E. Membere, P. Sails, Thermochemical characterization of brown seaweed, Laminaria digitata from UK shores, J. Anal. Appl. Pyrol. 131 (2018) 42-51.

[55] L.F. Chen, X.K. Bian, X.F. Lu, Removal of strontium from simulated low-level radioactive wastewater by nanofiltration, Water Sci. Technol. 78 (2018) 1733-1740.

[56] A. Haug, Dissociation of alginic acid, Acta Chem. Scand. 15 (1961) 950-952.

[57] K.D. Demadis, M. Paspalaki, J. Theodorou, Controlled release of bis(phosphonate) pharmaceuticals from cationic biodegradable polymeric matrices, Ind. Eng. Chem. Res. 50 (2011) 5873-5876.

[58] H. Sun, F.S. Cannon, X. He, Enhanced trifluoroacetate removal from groundwater by quaternary nitrogen-grafted granular activated carbon, Sci. Total Environ. 660 (2019) 577-585.

[59] Z.J. Li, A. Toyoshima, K. Tsukada, Y. Nagame, Ion-exchange behavior of Zr and Hf as homologues of element 104, Rf, in $\mathrm{H}_{2} \mathrm{SO}_{4}$ and $\mathrm{H}_{2} \mathrm{SO}_{4} / \mathrm{HClO}_{4}$ mixed solutions, Radiochim. Acta 98 (2010) 7-12.

[60] S. Bao, W. Hawker, J. Vaughan, Scandium loading on chelating and solvent impregnated resin from sulfate solution, Solvent Extr. Ion Exch. 36 (2018) 100-113.

[61] W.W. Wang, Y. Pranolo, C.Y. Cheng, Recovery of scandium from synthetic red mud leach solutions by solvent extraction with D2EHPA, Sep. Purif. Technol. 108 (2013) 96-102.

[62] N.K. Lazaridis, T.A. Pandi, K.A. Matis, Chromium(VI) removal from aqueous solutions by $\mathrm{Mg}-\mathrm{Al}-\mathrm{CO}_{3}$ hydrotalcite: sorption-desorption kinetic and equilibrium studies, Ind. Eng. Chem. Res. 43 (2004) 2209-2215.

[63] X. Sun, B. Peng, Y. Ji, J. Chen, D. Li, The solid-liquid extraction of yttrium from rare earths by solvent (ionic liquid) impreganated resin coupled with complexing method, Sep. Purif. Technol. 63 (2008) 61-68.

[64] J. Ma, Z. Wang, Y. Shi, Q. Li, Synthesis and characterization of lysine-modified SBA15 and its selective adsorption of scandium from a solution of rare earth elements, RSC Adv. 4 (2014) 41597-41604.

[65] S. Iftekhar, V. Srivastava, M. Sillanpaa, Enrichment of lanthanides in aqueous system by cellulose based silica nanocomposite, Chem. Eng. J. 320 (2017) 151-159.

[66] S. Giret, Y. Hu, N. Masoumifard, J.-F. Boulanger, E. Juere, F. Kleitz, D. Lariviere, Selective separation and preconcentration of scandium with mesoporous silica, ACS Appl. Mater. Interfaces 10 (2018) 448-457.

[67] M. Pegier, K. Kilian, K. Pyrzynska, Enrichment of scandium by carbon nanotubes in the presence of calcium matrix, Microchem. J. 137 (2018) 371-375.

[68] D.L. Ramasamy, V. Puhakka, E. Repo, M. Sillanpaa, Selective separation of scandium from iron, aluminium and gold rich wastewater using various amino and nonamino functionalized silica gels - a comparative study, J. Clean. Prod. 170 (2018) 890-901.

[69] Q. Yu, S. Ning, W. Zhang, X. Wang, Y. Wei, Recovery of scandium from sulfuric acid solution with a macro porous TRPO/ $\mathrm{SiO}_{2}-\mathrm{P}$ adsorbent, Hydrometallurgy 181 (2018) 74-81. 